SAND93-2291

Unlimited Distribution

Printed December, 1993

Distribution

Category UC- $-\mathrm{s}$

\title{
Impact Analysis of Minuteman III Payload Transporter Type III
}

\author{
Peter P. Stirbis \\ Solid and Structural Mechanics Department \\ Sandia National Laboratories \\ Albuquerque, New Mexico 87185
}

\begin{abstract}
An analysis of the impact of the Minuteman III Payload Transporter Type III into a nonyielding target at $46 \mathrm{~m} . \mathrm{p} . \mathrm{h}$. and $30 \mathrm{~m} . \mathrm{p} . \mathrm{h}$., and into a yielding target at $46 \mathrm{~m} . \mathrm{p}$.h. is presented. The analysis considers the structural response of the tiedown system which secures the Minuteman III re-entry system to the floor of the payload transporter. A finite element model of the re-entry system, its tiedown system, which includes tie-rods and shear pins, and the pallet plate which is attached to the transporter floating plate, was constructed. Because accelerations of the payload transporter are not known, acceleration data from one-quarter scale testing of the Safe Secure Trailer was used to investigate the response of the tiedown system. These accelerations were applied to the pallet plate. The ABAQUS computer code was used to predict the forces in the members of the tiedown system.
\end{abstract}

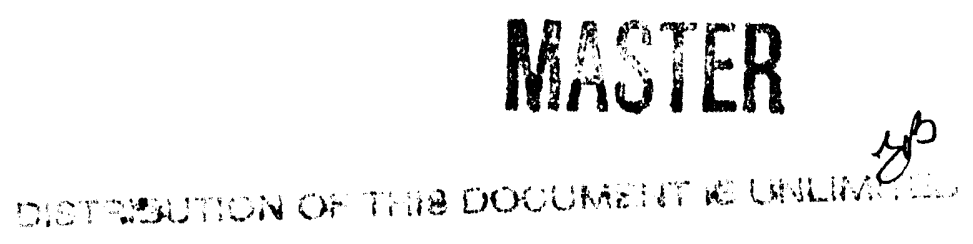




\section{Acknowledgments}

The effort of Barry D. Boughton, 9612, in obtaining funding for this project is greatly appreciated. In addition, this analysis would not have been possible without his tireless efforts in obtaining drawings and specifications of the PT Van and the MK12A re-entry system. The assistance of CPT Brent Bredehoft, HQDNA, and LCDR Kenneth Stein, HQDNA, is appreciated for obtaining the drawings, specifications, and for arranging inspection trips to visually inspect PT Van hardware. 


\section{Conversion Table}

\begin{tabular}{|l|l|l|}
\hline inch & $2.540000 \times \mathrm{xE}-2$ & meter $(\mathrm{m})$ \\
\hline in per sec & $2.540000 \times \mathrm{xE}-2$ & meter $/ \mathrm{sec}(\mathrm{m} / \mathrm{s})$ \\
\hline mile per hour & 4.470400 & meter $/ \mathrm{sec}(\mathrm{m} / \mathrm{s})$ \\
\hline $\begin{array}{l}\text { pound-force (lbs avoirdu- } \\
\text { pois) }\end{array}$ & 4.448222 & newton $(\mathrm{N})$ \\
\hline pound-force/inch**2 (psi) & $4.788026 \times \mathrm{xE}-2$ & kilo pascal $(\mathrm{kPa})$ \\
\hline acceleration in g's & 9.8145000 & meter $/ \mathrm{sec}^{* * 2}\left(\mathrm{~m} / \mathrm{s}^{* * 2}\right)$ \\
\hline
\end{tabular}




\section{Table of Contents}

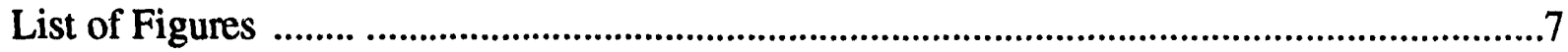

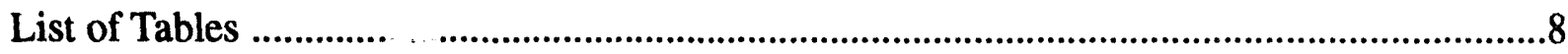

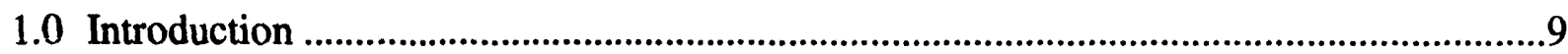

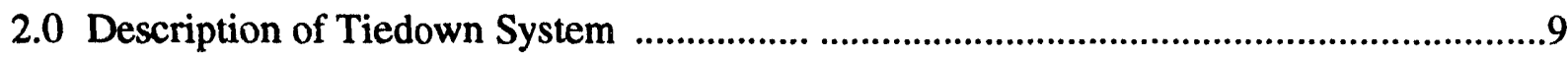

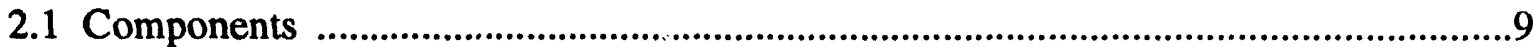

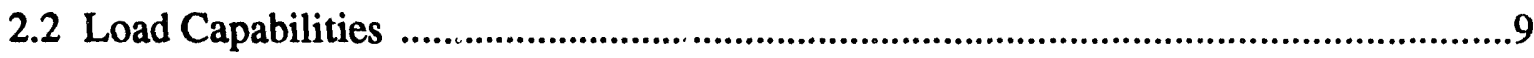

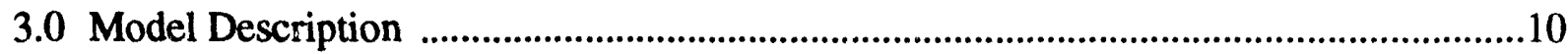

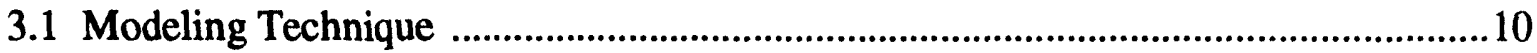

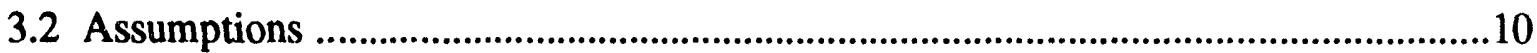

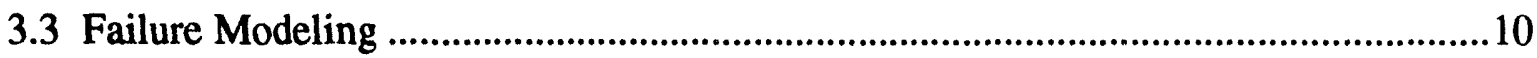

3.4 Approximate Acceleration Histories ..................................................................11

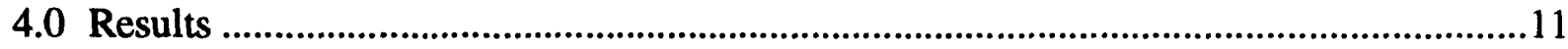

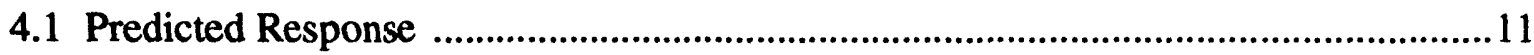

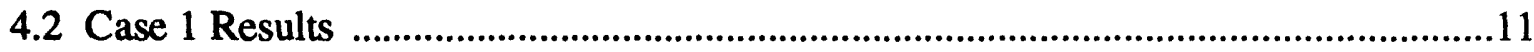

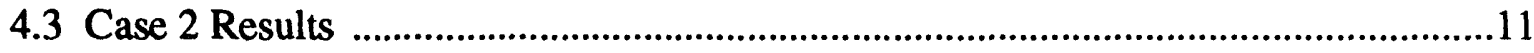

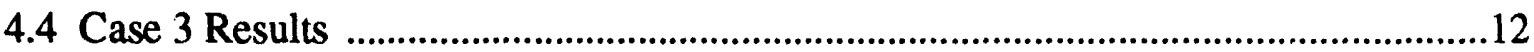

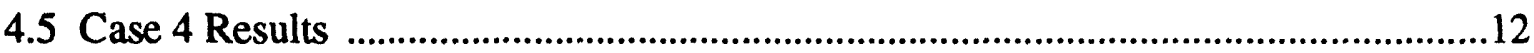

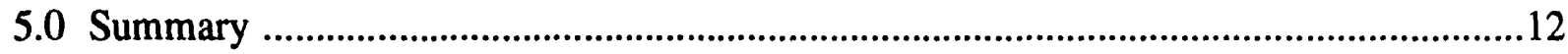

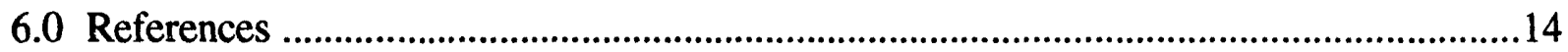

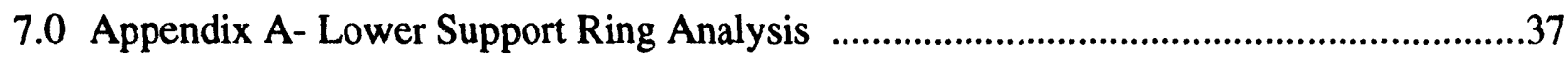

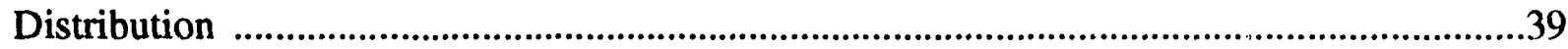




\section{List of Figures}

1. Finite element model of MK12 RES and pallet plate …...............................................15

2. Acceleration input for $46 \mathrm{mph}$ unyielding impact ......................................................16

3. Acceleration input for $30 \mathrm{mph}$ unyielding impact ....................................................17

4. Acceleration input for $46 \mathrm{mph}$ yielding impact ..........................................................18

5. Force in clamp pins, MK12 RES $46 \mathrm{mph}$ unyielding …...............................................19

6. Force in tie-rods, MK12 RES, $46 \mathrm{mph}$ unyielding ….....................................................20

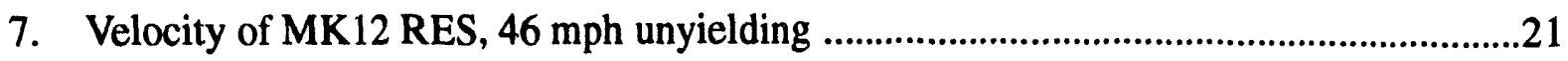

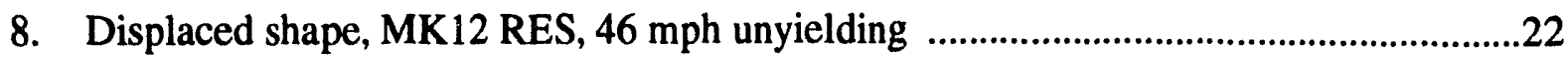

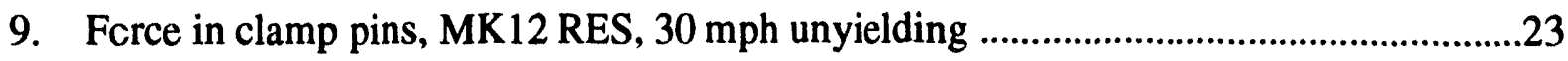

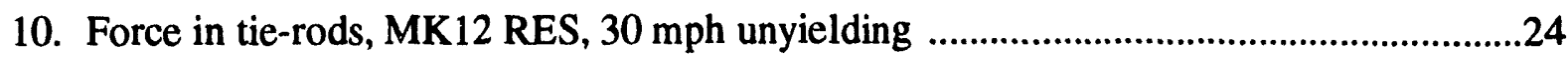

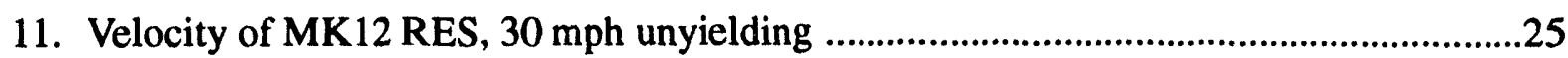

12. Displaced shape, MK12 RES, $30 \mathrm{mph}$ unyielding ………............................................26

13. Force in forward clamp pin, MK12 RES, $46 \mathrm{mph}$ yielding .............................................27

14. Force in aft clamp pins, MK12 RES, $46 \mathrm{mph}$ yielding ...................................................28

15. Force in tie-rods, MK12 RES, $46 \mathrm{mph}$ yielding ...........................................................29

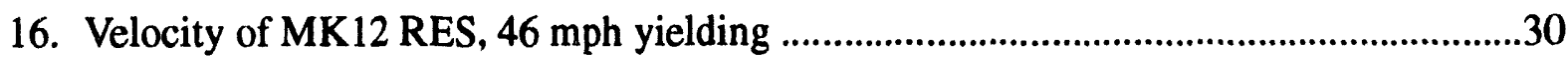

17. Displaced shape, MK12 RES, $46 \mathrm{mph}$ yielding ...........................................................31

18. Force in forward clamp pin, MK21 singlet RES, $46 \mathrm{mph}$ unyielding .............................32

19. Force in aft clamp pins, MK21 singlet RES, 46 mph unyielding ....................................33

20. Force in tie-rods, MK21 singlet RES, 46 mph unyielding ………...................................34

21. Velocity of MK21 singlet RES, $46 \mathrm{mph}$ unyielding ......................................................35

22. Displaced shape, MK21 singlet RES, 46 mph unyielding ...............................................36 


\section{List of Tables}

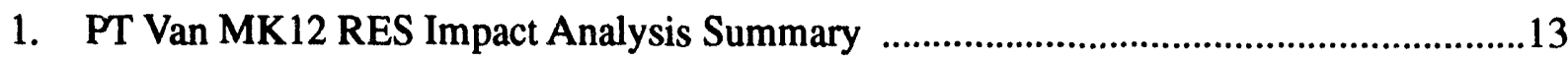

3 


\subsection{Introduction}

The Defence Nuclear Agency is conducting the W78 Minuteman III Weapon System Safety Assessment. This study involves assessing the vulnerability of the weapon system in all states of its existence including in-silo, storage, and transportation environments. The Minuteman III re-entry system (RES) is transported between Launch Facilities and Strategic Missile Support Bases, specifically Assembly, Surveillance and Inspection Buildings, using a tractor trailer combination vehicle of which the semi-trailer component is called the Payload Transporter Type III or PT Van.

A finite element analysis was conducted to assess the vulnerability of the re-entry system tiedown system to loads that might prevail in accidents involving collision of the PT Van with fixed objects or other vehicles. Because accelerations generated by collision of the PT Van are not known, acceleration data obtained from one-quarter scale testing of the Safe Secure Trailer [1] was used to investigate the response of the tiedown system.

The PT Van and the SST have vastly different structures and are not likely to generate the same acceleration for the same impact conditions. A full scale impact test of a PT Van is necessary to provide information about the crush mechanisms and data which could be used to develop a more accurate finite element model of the transporter system. Without actual PT Van impact results, using the scale model SST acceleration data is probably the most the reasonable method to obtain estimates of the response of the Minuteman III payload. The results of these analyses must therefore be treated with appropriate uncertainty in the probabilistic risk assessment of the PT Van transportation.

\subsection{Description of Tiedown System}

\subsection{Components}

The RES and tiedown system is shown in Figure 1. A support ring (67E54135) is attached to the RES near the center of gravity. The support ring is not shown in this model but it is described in more detail and analyzed as a separate structure in Appendix A of this report. Four tie- rod assemblies (67D54062) are located between the support ring and pallet plate (67E56318). Six pallet plate clamps (69D52404) have pins which engage six of the 48 bolt holes at the aft end of the RES. The pallet plate clamps are not shown in this view of the model but they are included in the analysis. There are two clamps at the forward side of the RES and four clamps are located on the aft side of the RES. Each pallet plate clamp has a shear pin which engages a hole in a ring at the bottom of the RES. Each clamp is bolted to the pallet plate with a $1 / 2$ inch dianieter bolt.The pallet plate is bolted to the air pallet floating plate (882T 9100300 ) with 4 each $1 / 2$ inch diameter bolts. The air-pallet-plate is not included in the model.

\subsection{Load Capabilities}

The four tie-rods and the six pallet plate clamps are the critical elements in the restraint of the RES. Each tie-rod is made from AISI 1018 steel and has 5/16-24 threads. The calculated ultimate tensile strength based on the net tensile area at the threads is $4350 \mathrm{lb}$ per rod. The $3 / 8$ inch diameter shear pin in the pallet plate clamp is made from AISI 4140 steel and has a calculated shear strength of $14,300 \mathrm{lb}$. The four clamp bolts are made from AISI 1095 steel 
and each has a tensile strength of $21,400 \mathrm{lb}$. The four bolts attaching the pallet-plate to the air pallet floating plate are made from AISI 4340 steel and each has a tensile strength of 24,200 lb.

\subsection{Model Description}

\subsection{Modeling Technique}

A vertical symmetry plane was used to model one-half of the RES and pallet plate since only loading in the longitudinal direction of the PT Van was analyzed.

A finite element model of the RES, pallet plate, and the four tie-rods was generated with PATRAN [2] and the dynamic response during an impact was determined with the ABAQUS/ Explicit code [3]. The mesh model is shown in Figure 1. The detailed structure of the RES was not modeled, rather it was approximated as a 1.00 inch thick shell using 4 node quadrilateral shell elements. Material properties were chosen to obtain the appropriate weight and center of gravity. The pallet plate was modeled with 4 node quadrilateral shell elements and 2 node beam elements.

Two RES configurations were modeled: a triplet configuration consisting of three MK12A's and the re-entry system hardware and a singlet configuration consisting of one MK21 and the re-entry system hardware. The Minuteman III normally carries three MK12A re-entry vehicles, but an alternate proposal is to carry a single MK21 re-entry vehicle. The weight of the three MK12 A re-entry vehicles was included in the weight of the RES shell. One calculation was made with the weight of one MK21 included in the weight of the RES shell.

The six pallet clamps and shear pins were modeled with 2 node beam elements placed between the pallet plate and the bottom of the RES. The tie-rods were modeled as 2 node beam elements between the senter of gravity of the RES and the pallet plate.

The RES and pallet were given a uniform velocity in the horizontal direction. The deceleration due to impact was applied as a force on the pallet plate at the location of the bolted connections to the air pallet floating plate. The force-time histories used are described in section 3.4, "Approximate Acceleration Histories".

\subsection{Assumptions}

The support ring attached to the RES at its center of gravity was not modeled. Appendix 1 shows that the ring is less critical than the tie-rods.

The air pallet floating plate is not modeled. It is assumed to be stronger than the RES tiedown system. Although the plate "floats" on its air suspension, it does have stops that limit the displacement after a certain amount of travel.

\subsection{Failure Modeling}

The tensile failure strength of the tie-rods and the shear failure strength of the clamp block shear pins were modeled with the ABAQUS/Explicit ductile failure model. This model allows the stable removal of elements from the mesh as they exceed the failure criteria, therefore allowing modeling of the sequential failure of the various tiedown components. The failure 
loads were discussed in 2.2. The failure model is based on the value of equivalent plastic strain.When the equivalent plastic strain at a material point reaches the value defined as the plastic failure strain, the material point is failed. If all the material points in the element fail, the element loses its ability to resist any further load and, hence, it is removed from the mesh.

\subsection{Approximate Acceleration Histories}

The approximate acceleration-time histories for the SST van impacting an unyielding target at $46 \mathrm{mph}$ and $30 \mathrm{mph}$, and impacting a yielding target at $46 \mathrm{mph}$ are shown in Figures 2, 3, and 4. These simplified accelerations were obtained from Reference 1.

The weight of the RES with three MK12A's or one singlet MK21 was multiplied by these accelerations to obtain force histories which were then applied to the finite element model of the RES and payloads at the bolt locations on the pallet plate. The results for the MK21 singlet configuration would bound those of a MK12A singlet configuration because of the increased weight of the MK21.

\subsection{Results}

\subsection{Predicted Response}

The predicted response was computed for four impact conditions for the PT Van:

1) $46 \mathrm{mph}$ into an unyielding target at 90 degrees with RES MK12A triplet configuration.

2) $30 \mathrm{mph}$ into an unyielding target at 90 degrees with RES MK12A triplet configuration.

3) $46 \mathrm{mph}$ into a yielding target at 90 degrees with RES MK12A triplet configuration.

4) 46 mph into an unyielding target at 90 degrees with RES MK21singlet configuration.

\subsection{Case 1 Results}

The force -time histories for the forward and aft clamp pins are shown in Figure 5. The clamp pins have failed after 0.15 seconds. Figure 6 shows the force history for the aft and forward tierods. The tie-rods fail after 0.17 seconds. Figure 7 shows the velocity of the top, center of gravity, and bottom of the RES. It shows the tumbling of the RES after about 0.15 seconds. Note that the residual velocity of the center of gravity has a steady-state value of $310 \mathrm{in} / \mathrm{sec}$ $(17.6 \mathrm{mph})$. Figure 8 shows the original position of the RES and the position at 0.200 seconds, after the tie-down system has failed.

\subsection{Case 2 Results}

The force -time histories for the forward and aft clamp pins are shown in Figure 9. The clamp pins have failed after 0.30 seconds. Figure 10 shows the force history for the aft and forward tie-rods. The tie-rods fail after 0.60 seconds. Figure 11 shows the velocity of the top, center of gravity, and bottom of the RES. It shows the tumbling of the RES after about 0.30 seconds. Note that the residual velocity of the center of gravity is basically zero at 1.0 seconds. Figure 12 shows the original position of the RES and the position at 1.00 seconds, after the tie-down system has failed. 


\subsection{Case 3 Results}

The force -time histories for the forward and aft clamp pins are shown in Figure 13 and 14. The maximum predicted force of $7300 \mathrm{lb}$ is well below the $14,300 \mathrm{lb}$ load capability of the pin. The clamp pins have not failed after 0.50 seconds. Figure 15 shows the force history for the aft and forward tie-rods. The maximum predicted force of $1200 \mathrm{lb}$ is well below the $4350 \mathrm{lb}$ tensile capability of the tie-rod. The tie-rods have not failed after 0.50 seconds. Figure 16 shows the velocity of the top, center of gravity, and bottom of the RES. It shows almost uniform translational velocity. Figure 17 shows the original position of the RES and the position at 0.500 seconds with the RES still attached to the pallet plate.

\subsection{Case 4 Results}

The force -time histories for the forward and aft clamp pins are shown in Figure 18 and 19. The maximum predicted force of $10,500 \mathrm{lb}$ is well below the $14,300 \mathrm{lb}$ load capability of the pin. The clamp pins have not failed after 0.50 seconds. Figure 20 shows the force history for the aft and forward tie-rods. The maximum predicted force of $1700 \mathrm{lb}$ is well below the $4350 \mathrm{lb}$ tensile capability of the tie-rod. The tie-rods have not failed after 0.50 seconds. Figure 21 shows the velocity of the top, center of gravity, and bottom of the RES. It shows the almost uniform translational velocity. Figure 22 shows the original position of the RES and the position at 0.300 seconds with the RES still attached to the pallet plate.

\subsection{Summary}

The largest amount of uncertainty with respect to the use of these results is that the SST acceleration histories were used because PT Van structural response data does not exist. The PT Van and SST have vastly different structures and are likely to result in significantly different acceleration for the same accident conditions. It is extremely difficult to estimate how accelerations for the PT Van will compare with those of the SST simply based on knowledge of the two structures and engineering judgement. In the author's opinion, it is not unreasonable to expect that the impact velocities that result in release may differ by as much as a factor of two.

A full scale test of a PT Van would provide the information about the crushing mechanisms that could be incorporated into a finite element model. The confidence in the computational results for various crash events would be greater than for the technique used in this analysis.

The response of the MK12A RES, and the RES with a MK21 singlet, has been analyzed for impacts of the PT Van into non-yielding and yielding targets at 46 and $30 \mathrm{mph}$. The results are summarized in Table 1.

The analysis predicts that the cargo will release in the first two cases at $46 \mathrm{mph}$ and $30 \mathrm{mph}$ into an unyielding target with the MK12A triplet. In both cases the forward and aft clamp pins and tie-rods are predicted to fail. This would seem to provide reasonable certainty that the RES would separate from the pallet plate. The last two cases at $46 \mathrm{mph}$ into a yielding target with the MK12A triplet and $46 \mathrm{mph}$ into an unyielding target with the MK21 singlet are predicted not to break loose. In case 3, the maximum forces developed are about $50 \%$ of the clamp pin capacity. In case 4 , the maximum forces developed are about $73 \%$ of the clamp pin capacity. With these margins, it would seem there is reasonable certainty that the cargo would remain 
attached to the pallet plate.

Table 1: PT Van MK12 RES Impact Analysis Summary

\begin{tabular}{|c|l|l|c|c|}
\hline $\begin{array}{c}\text { Impact } \\
\text { Velocity } \\
\text { m.p.h. }\end{array}$ & \multicolumn{1}{|c|}{ Target } & \multicolumn{1}{|c|}{ Cargo } & $\begin{array}{c}\text { Cargo } \\
\text { Release }\end{array}$ & $\begin{array}{c}\text { Release Velocity } \\
\text { m.p.h.(in/sec) }\end{array}$ \\
\hline \hline 46 & 90 deg Unyielding & RES + MK12A & yes & $17.0(310)$ \\
\hline 30 & 90 deg Unyielding & RES + MK12A & yes & $0.0(0.0)$ \\
\hline 46 & 90 deg Yielding & RES + MK12A & no & - \\
\hline 46 & 90 deg Unyielding & $\begin{array}{l}\text { RES + MK21 } \\
\text { Singlet }\end{array}$ & no & \\
\hline
\end{tabular}




\subsection{References}

1. J. K. Deuel, Jr., "One-Quarter-Scale Model Impact Testing of the Safe Secure Trailer," Sandia National Laboratories, Albuquerque, NM, Currently in progress.

2. PATRAN Plus User's Manual, Volumes I and II, Release 2.4.

3. ABAQUS/EXPLICIT Users Manual, Version 5.0, Hibbit, Karlsson, \& Sorenson, Inc., Pawtucket, R.I. 


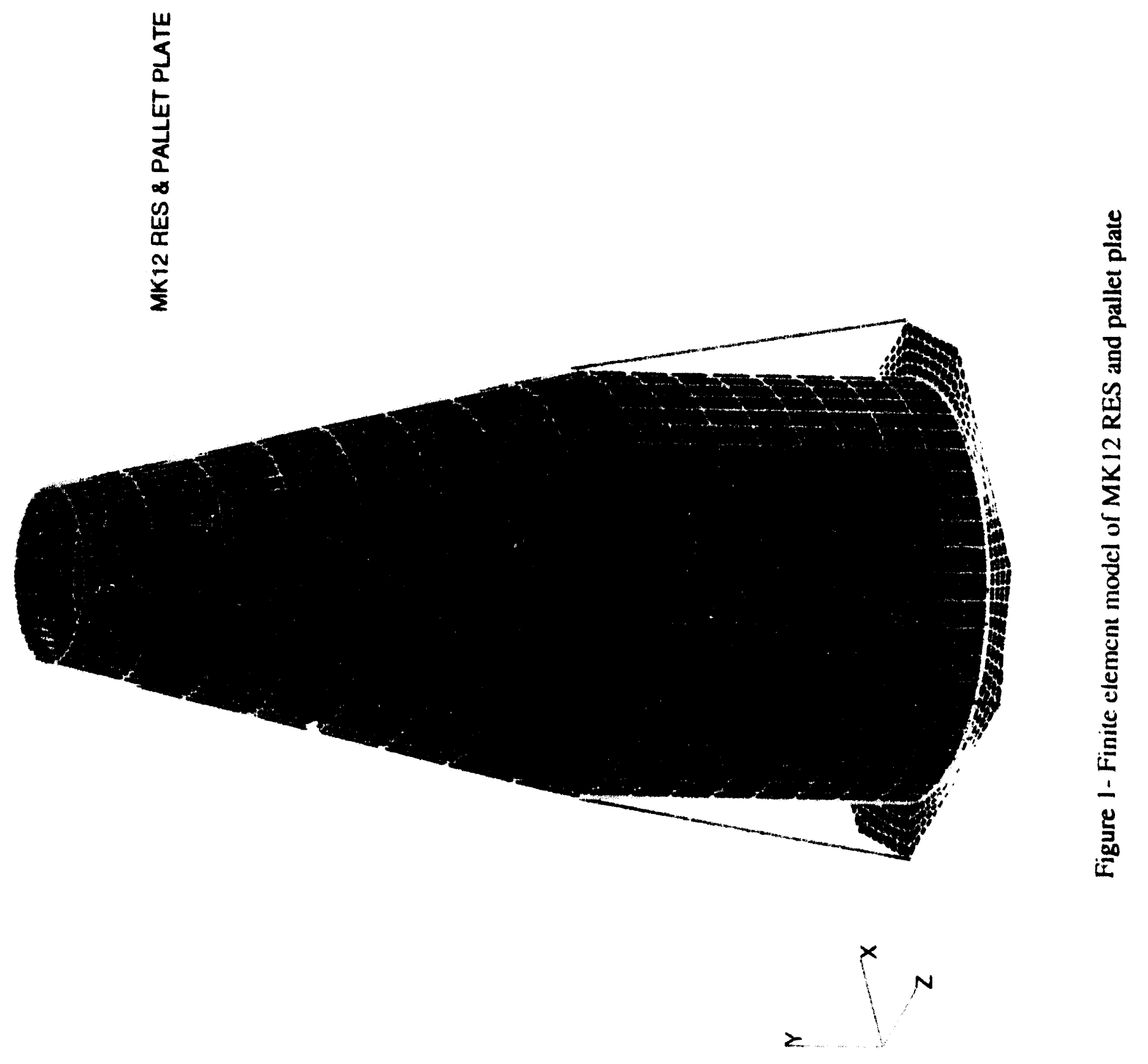




\section{6 mph - 90 deg, Unyielding}

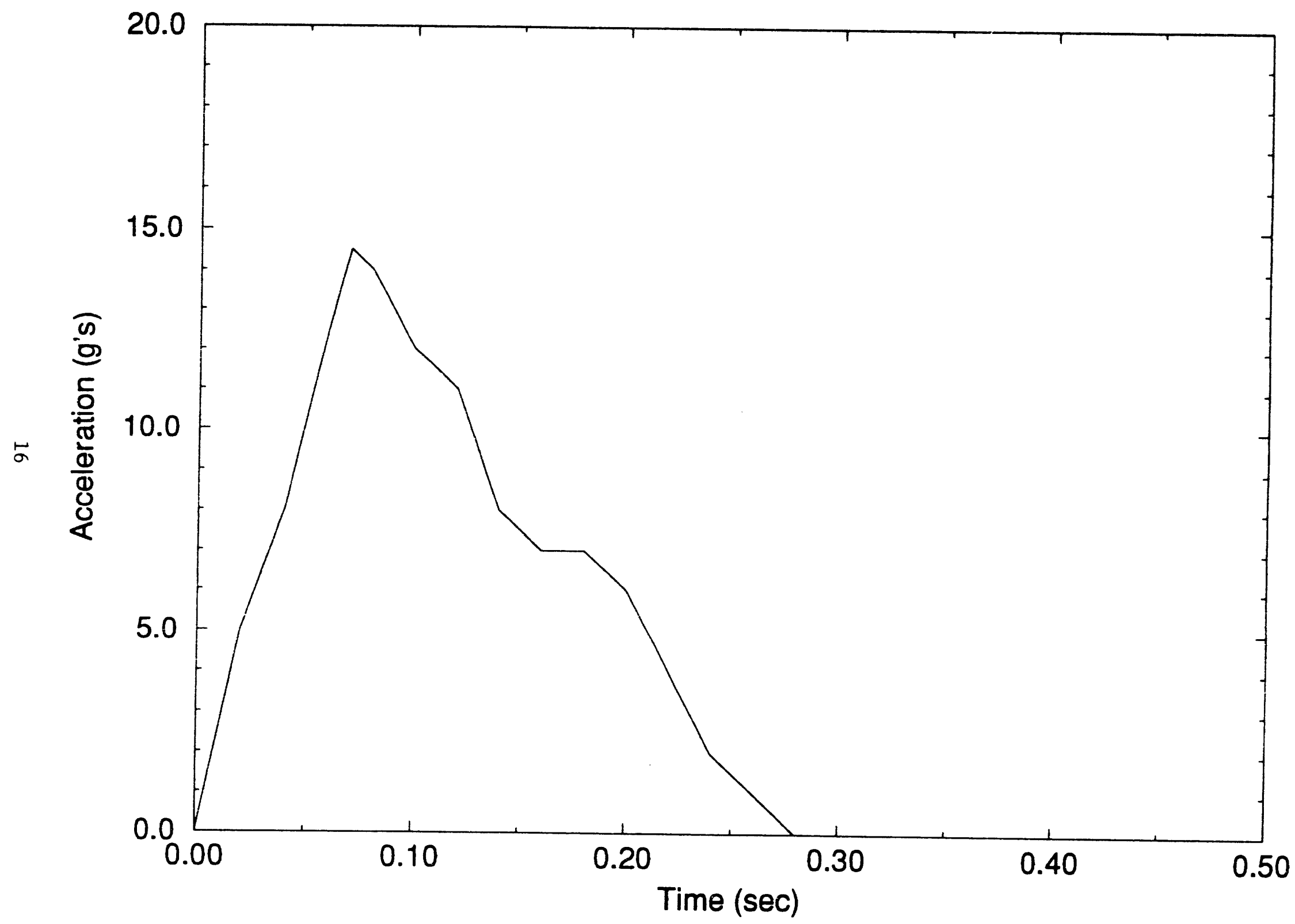

Figure 2- Acceleration input for $46 \mathrm{mph}$ unyielding impact 


\section{$30 \mathrm{mph}-90 \mathrm{deg}$, Unyielding}

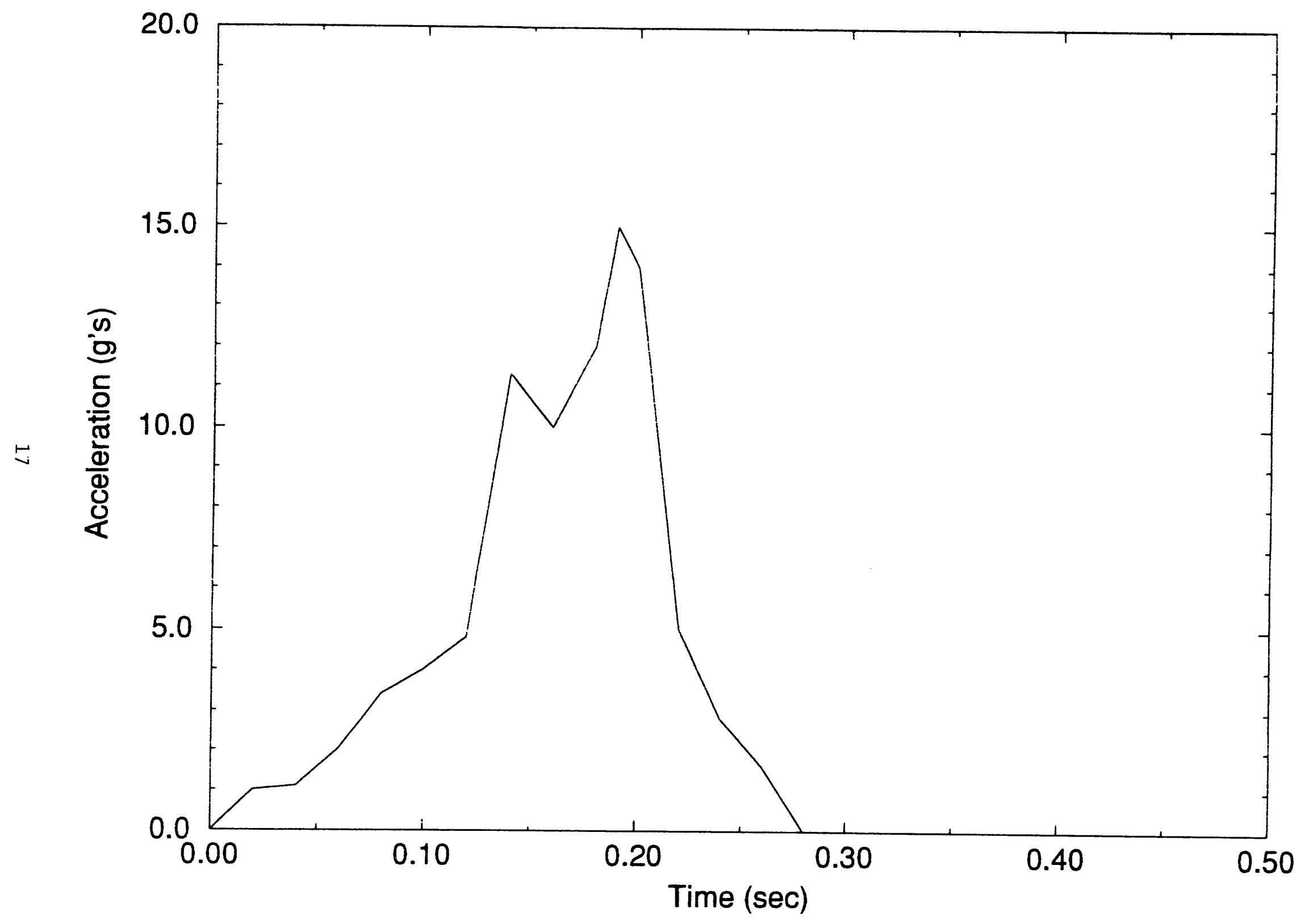

Figure 3- Acceleration input for $30 \mathrm{mph}$ unyielding impact 


\section{6 mph-90 deg, Yielding}

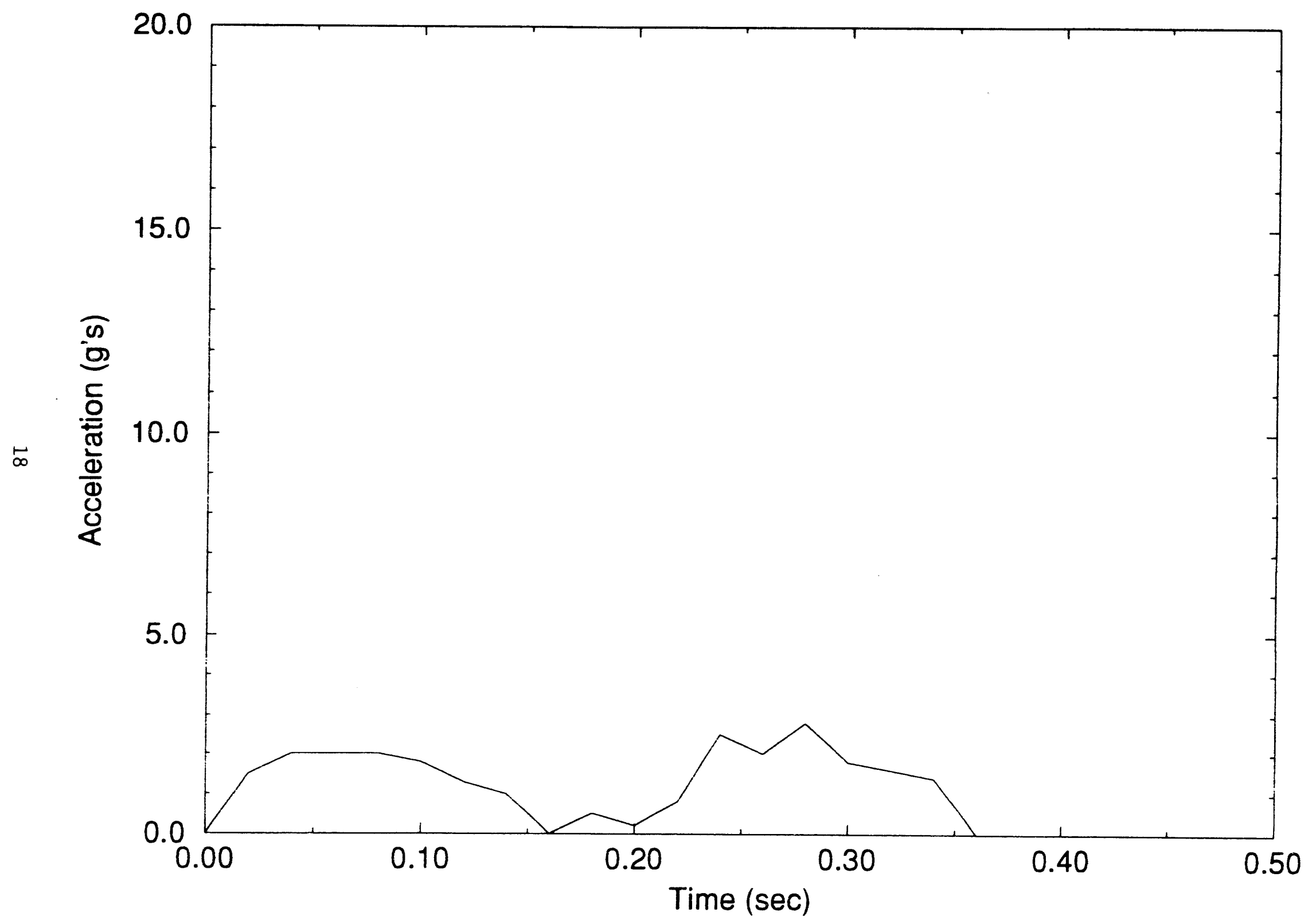

Figure 4- Acceleration input for $46 \mathrm{mph}$ yielding impact 

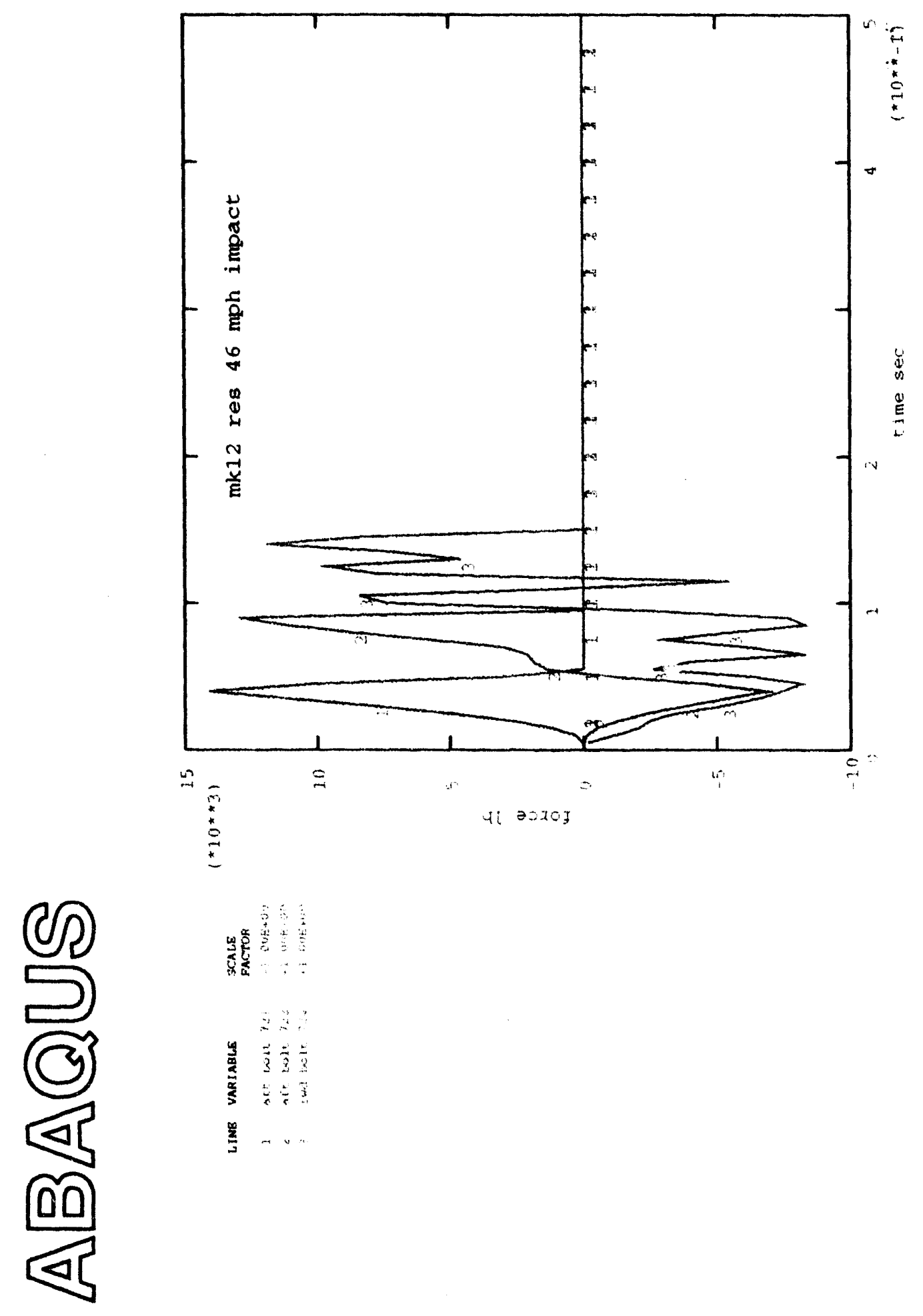

告 


\section{A回@US}

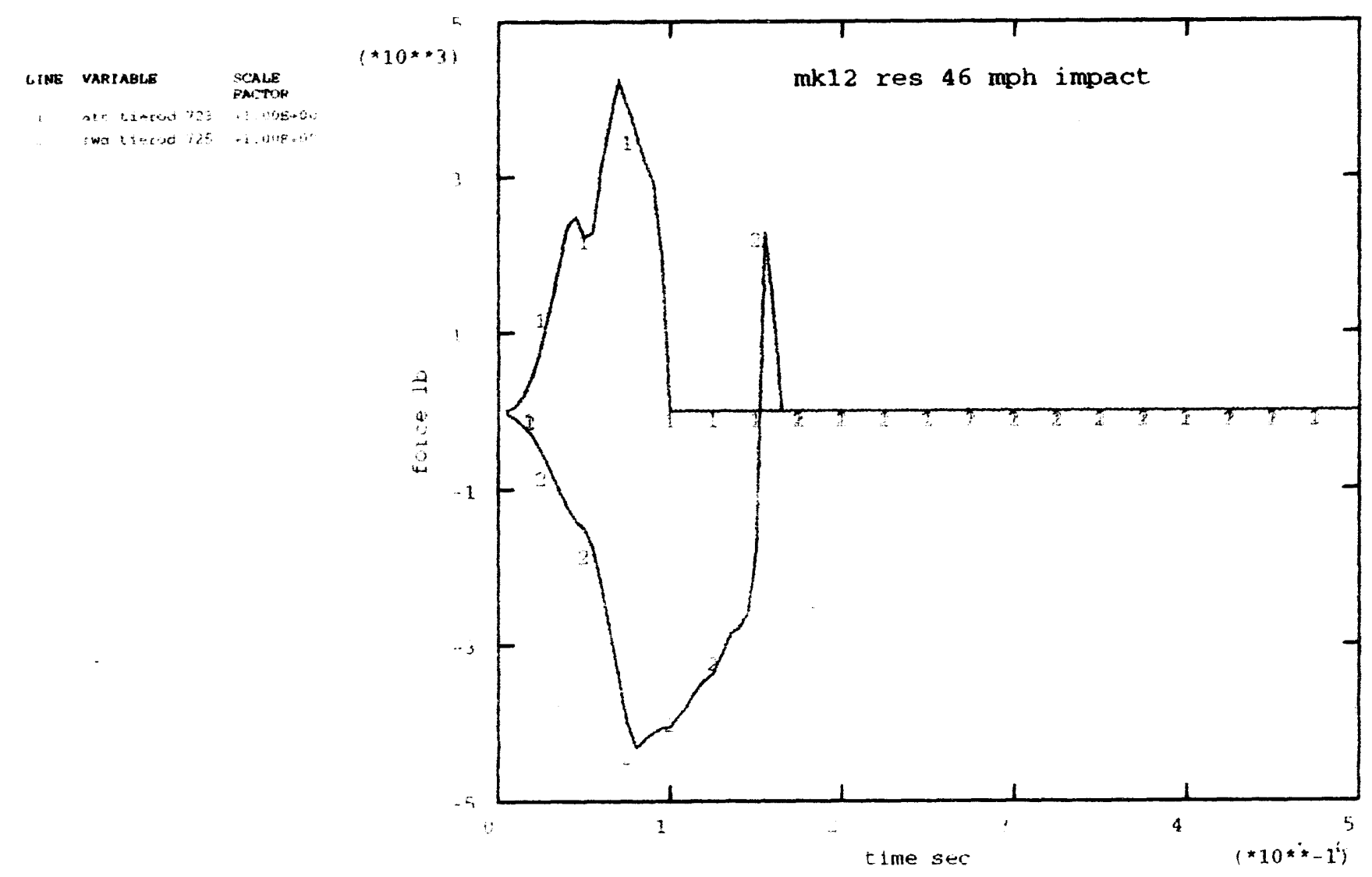

Figure 6- Force in tie-rods, MK12 RES, 46 mph unyielding 


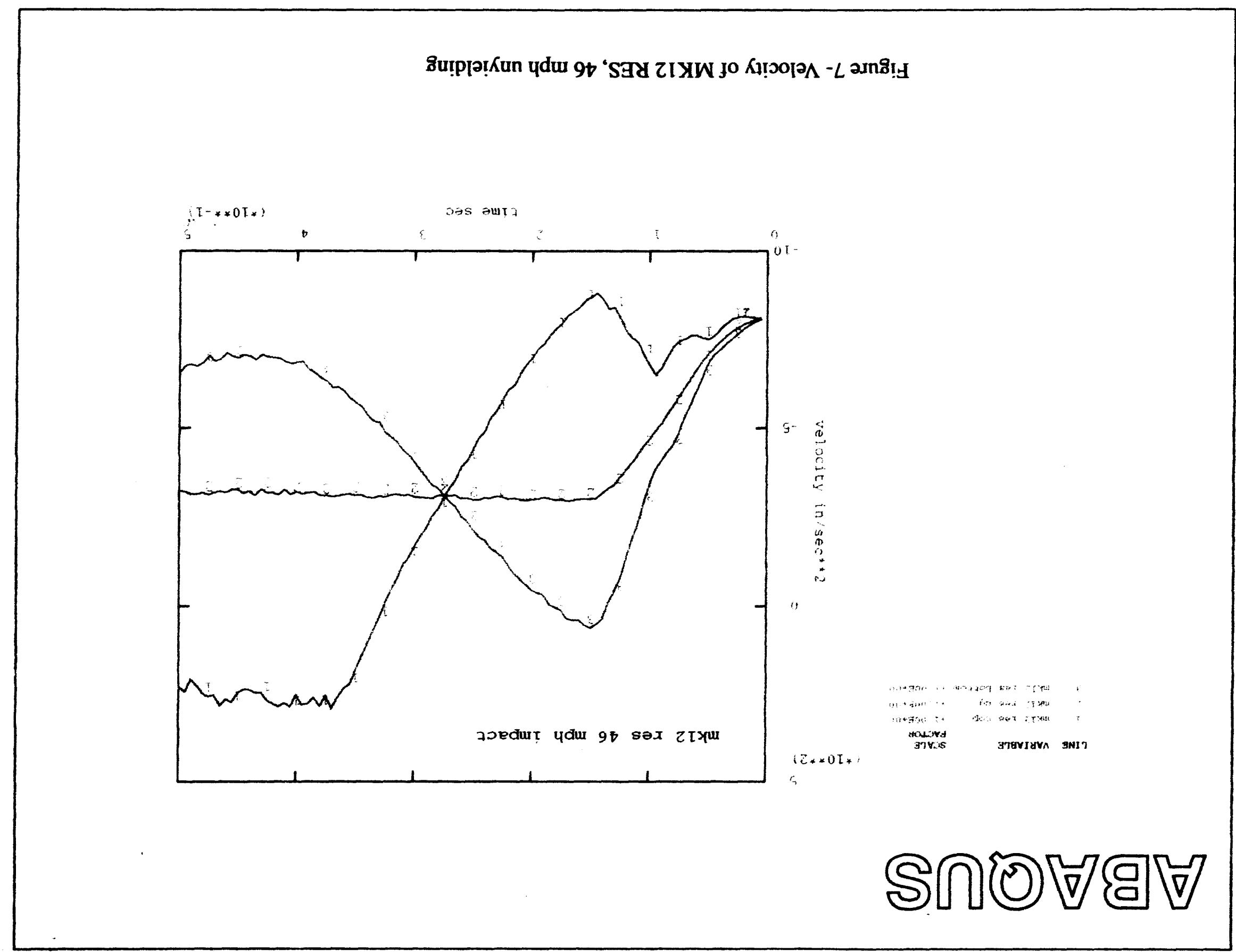




\section{A回QUS}
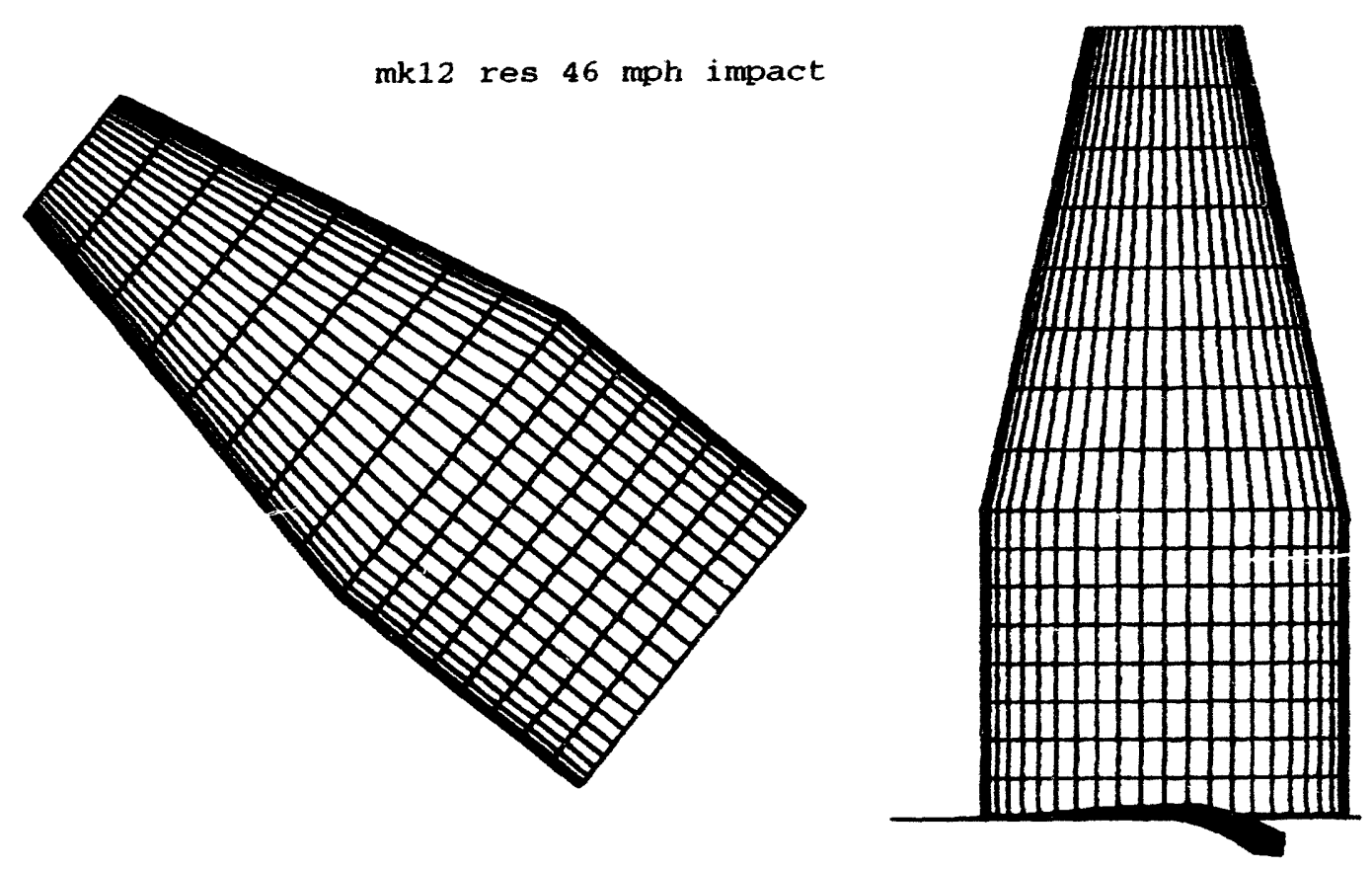

DISPLACEMENT MAGNIFICATION PACTOR $=1.00$

PIOIMAL MESH

TIME COMPLETED IM THIS STEP 0.200 TOTAL ACCUMULATED TIME 0.200

ABAOUS VERSION: $5.2-1$ DATE: 12 -JUL-93 TIME: 10:02:36 STEP 1 INCREMENT 111864

Figure 8- Displaced shape, MK12 RES, 46 mph unyielding 


\section{ABAQUS}

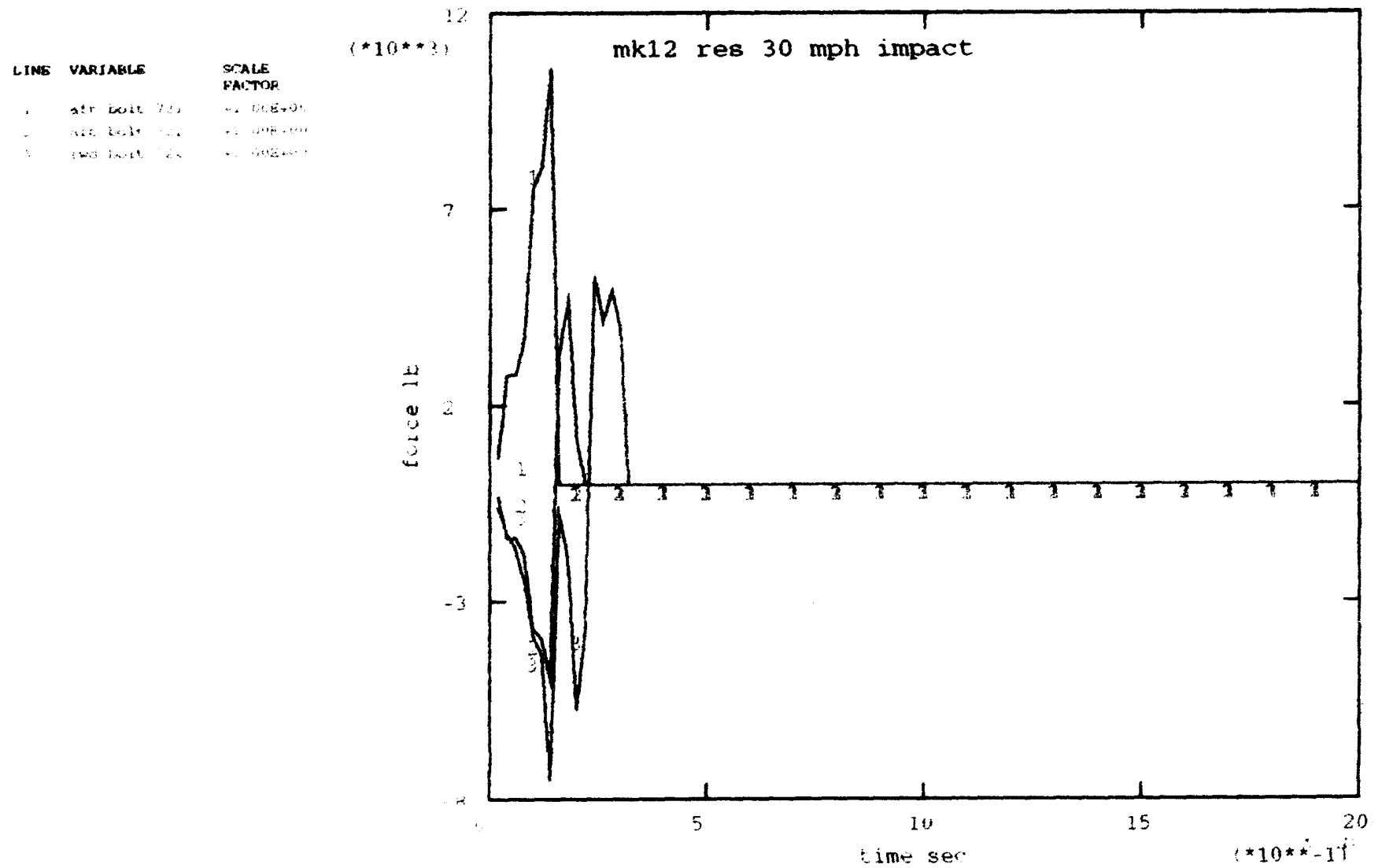

Figure 9- Force in clamp pins, MK12 RES, 30 mph unyielding 


\section{A回@US}

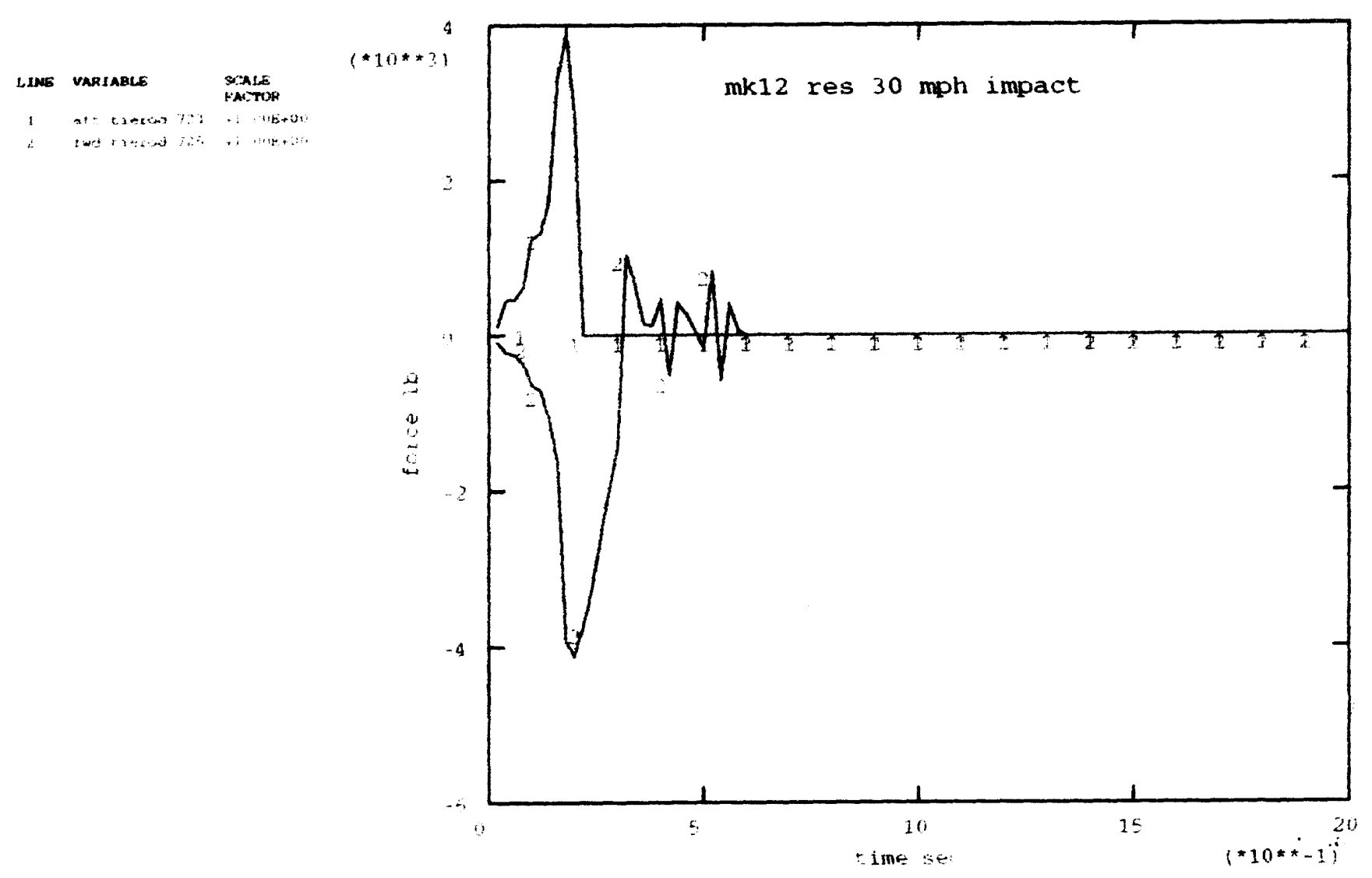

Figure 10- Force in tie-rods, MK12 RES, 30 mph unyielding 


\section{A回@US}

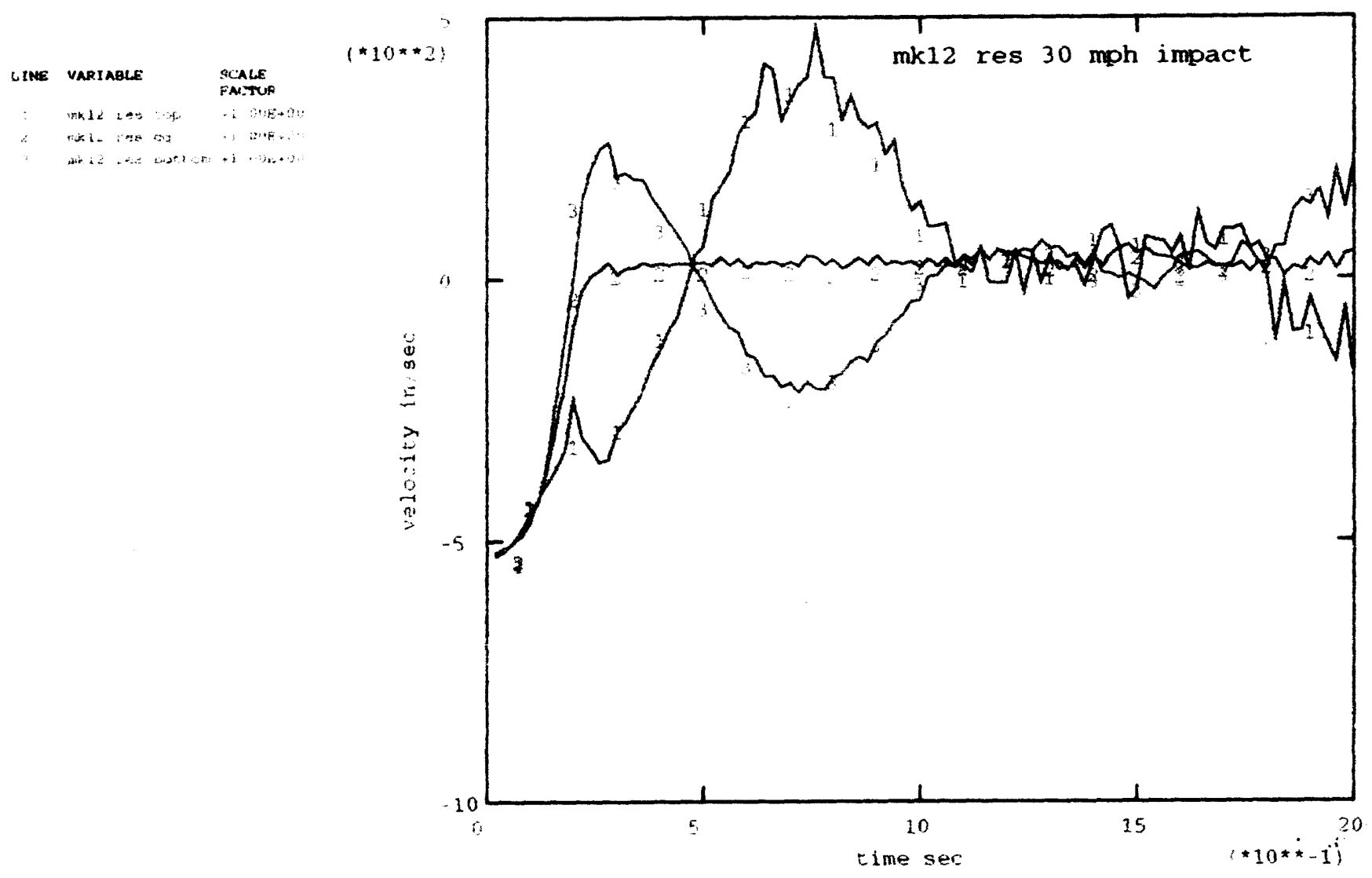

Figure 11- Velocity of MK12 RES, $30 \mathrm{mph}$ unyielding 


\section{ARAQUS}

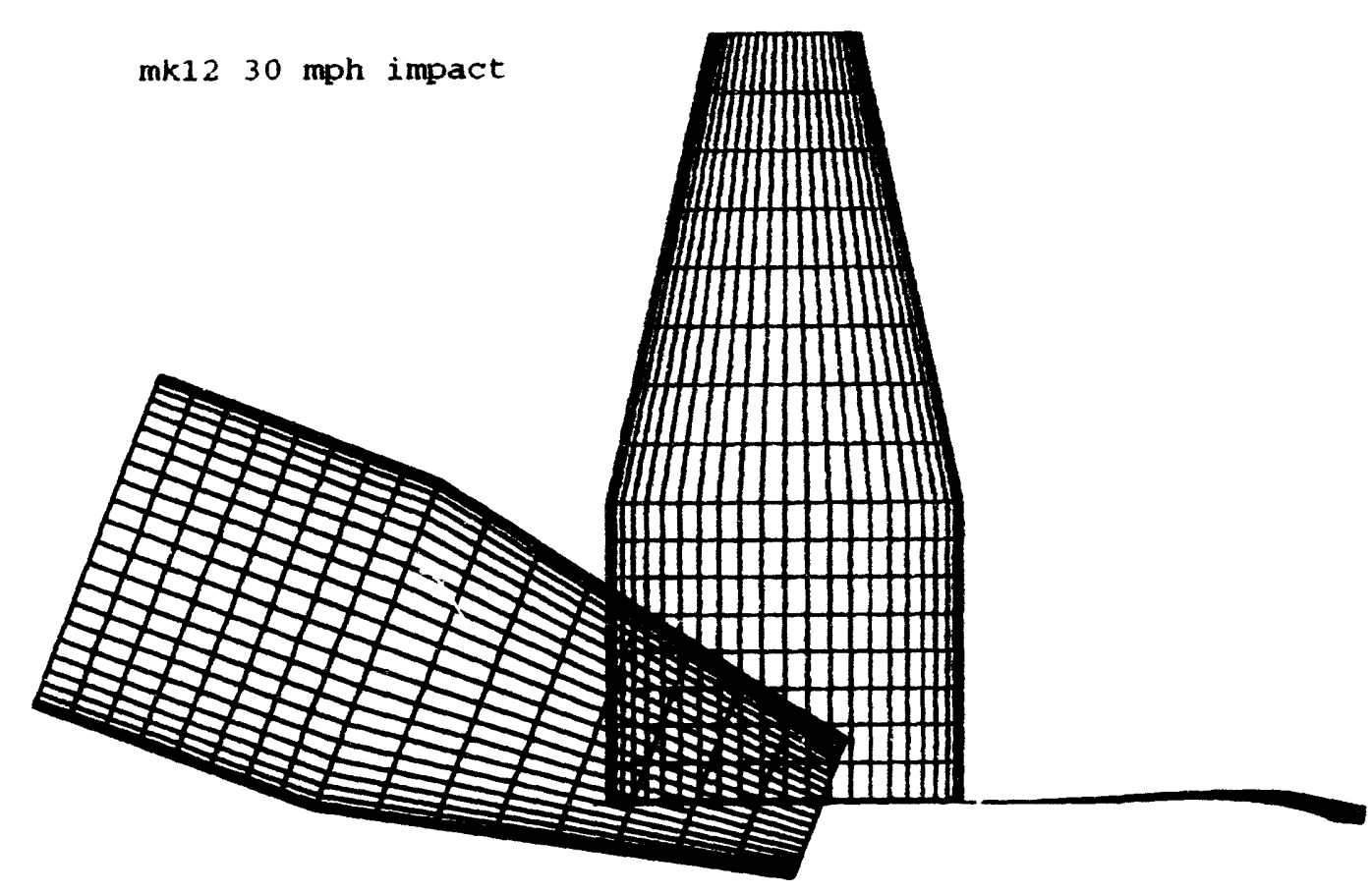

DSPLLACEMENT MAGNIFICATION FACTOK $=1.00$

IPIOTHAL MESH

DISPLACED MESH TIME COMPLETED IN THIS STEP 1.00 TOTAL ACCUMULATEU TIME 1.00

AEADUS VERGION: C $2 \%$ DATE: $12-$-JUL-93 TIME: 15:44:10 STEP 1 INCREMENT 559299

Figure 12- Displaced shape, MK12 RES, $30 \mathrm{mph}$ unyielding 


\section{A囵@US}

$\div \therefore, \ldots$

mk12 res $46 \mathrm{mph}$ yielding target

wi bo

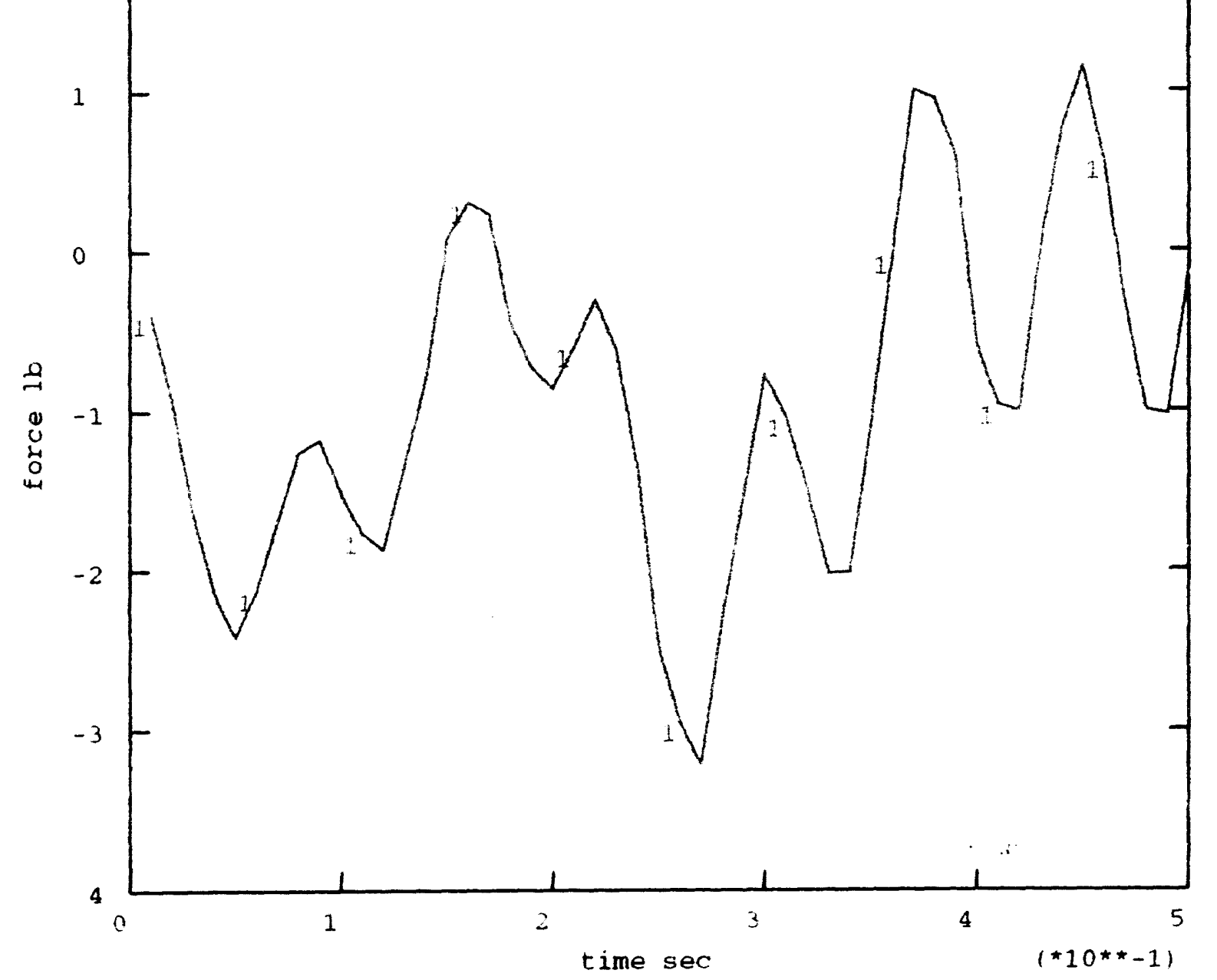

Figure 13- Force in forward clamp pin, MK12 RES, $46 \mathrm{mph}$ yielding 


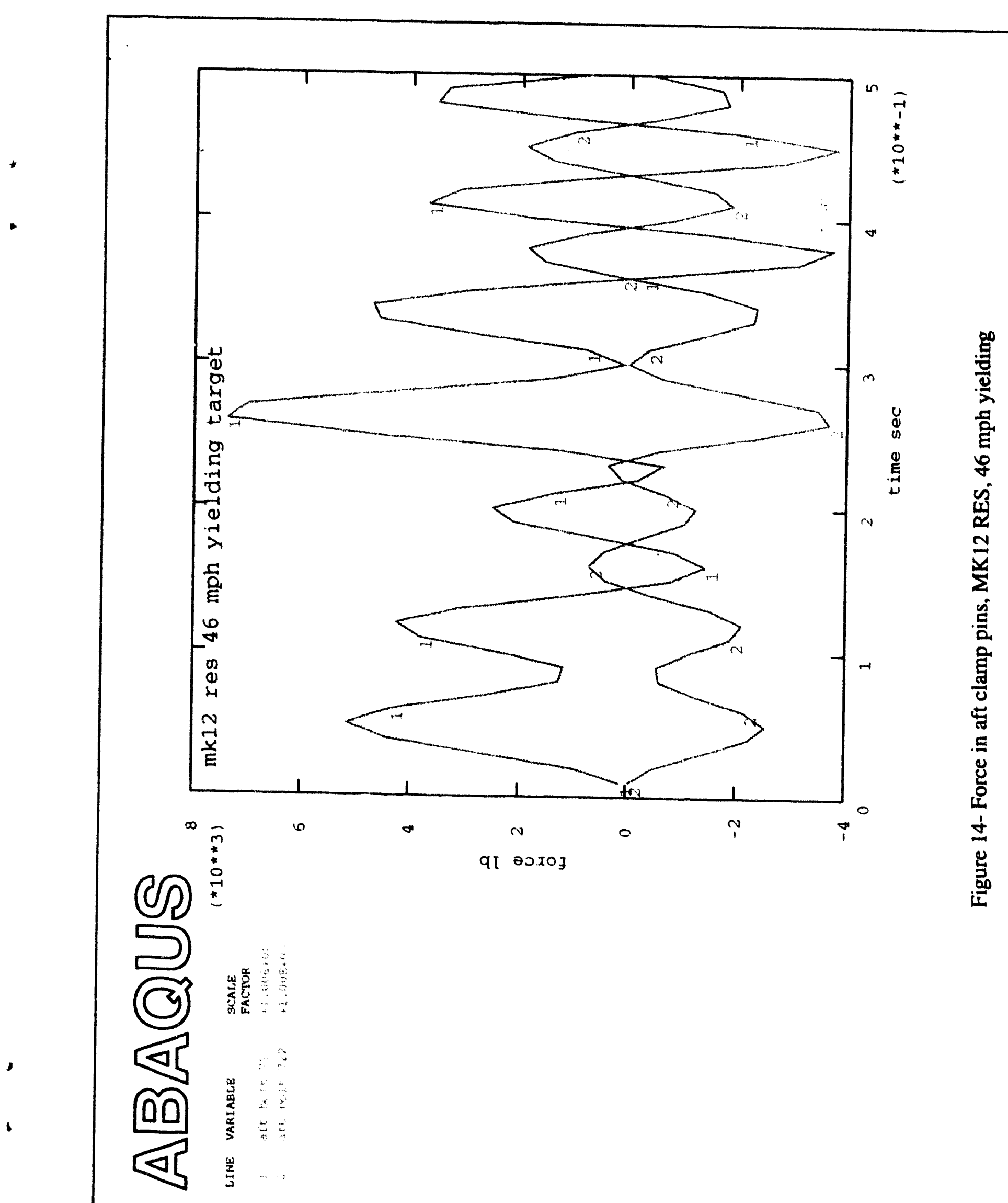




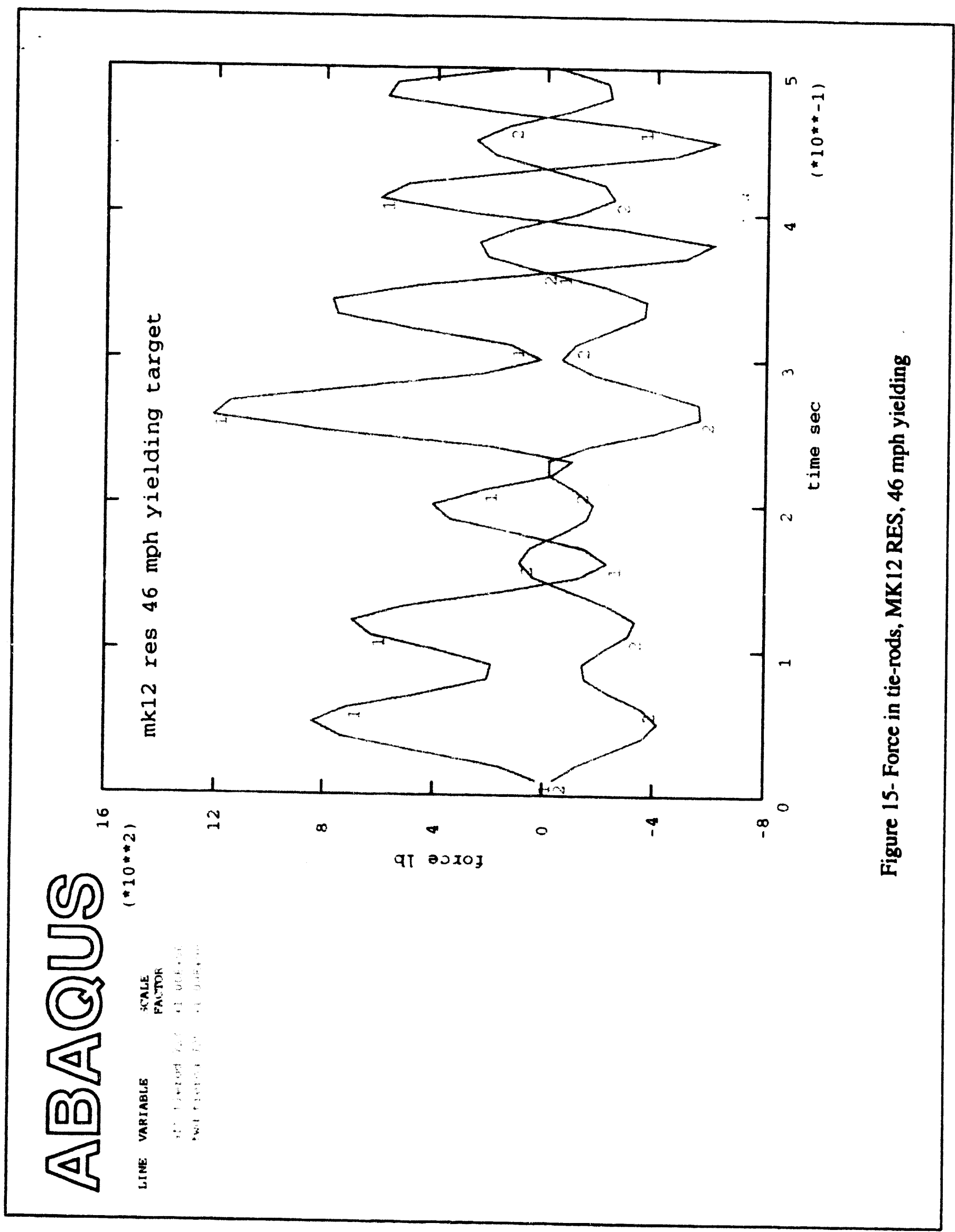




\section{A田@US}

LINE VARIABLE

FACTOR

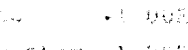

$(* 10 * \star 1)$

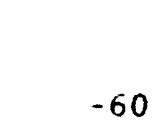

mk12 res 46 mph yielding target

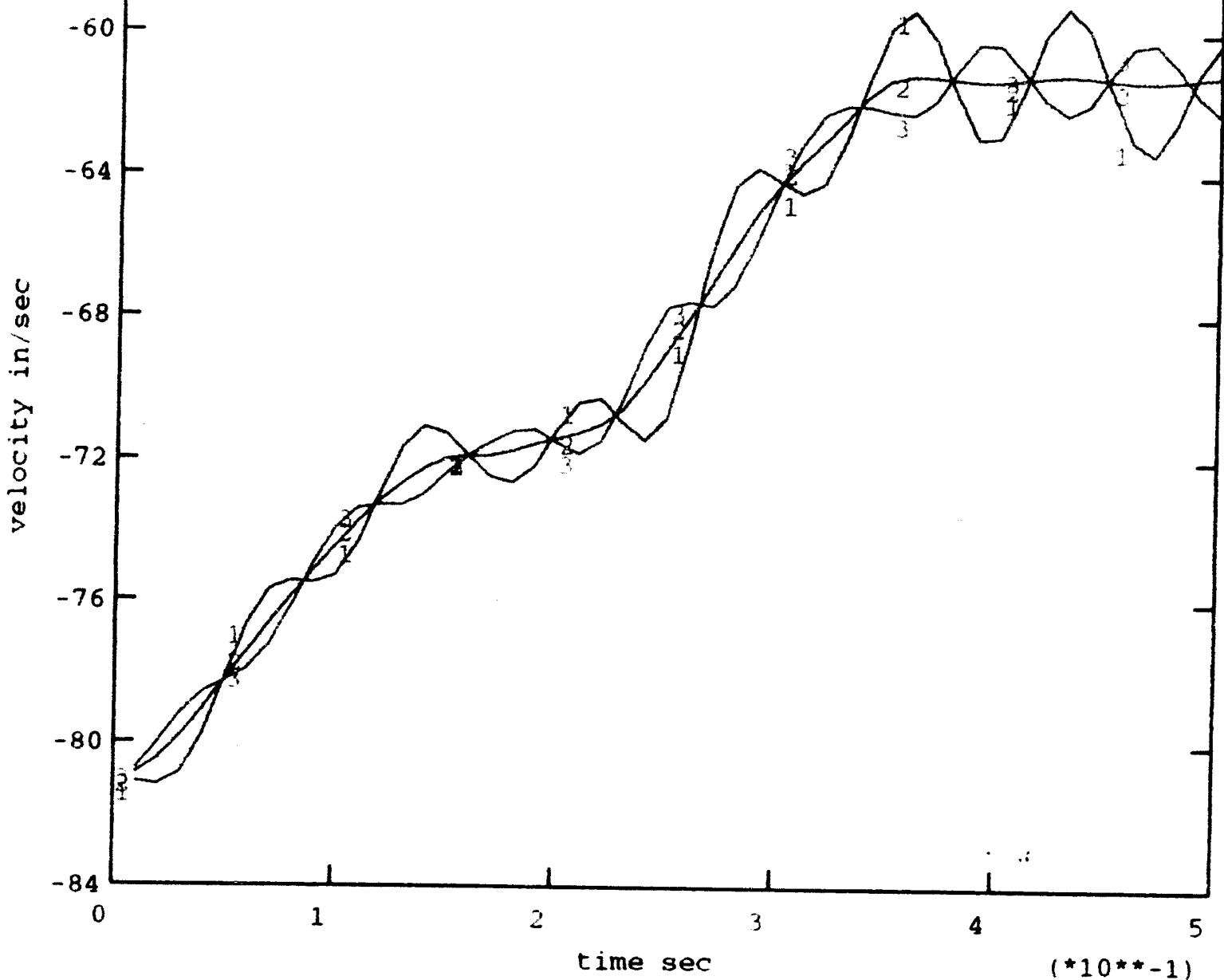

Figure 16- Velocity of MK12 RES, $46 \mathrm{mph}$ yielding 


\section{ABDAUS}

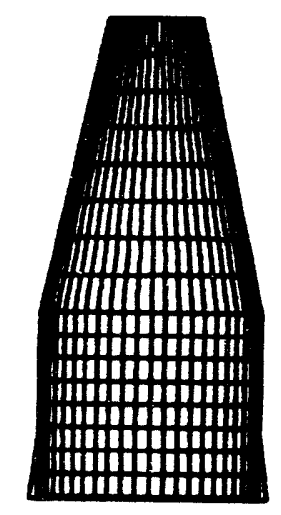
DISPLACEMENT MAGNIFICATION FACTOR $=1.00$
PRIINAL MESH
DISPLACED MESH

TIME COMPLETED IN THIS STEP 0.500 TOTAL ACCUMULATED TIME 0.500

ABAOIIS VERSION: $3.2-1$ DATE: 05 -MAY-43 TIME: $15: 48: 23$ STEP 1 INCREMENT 279600

Figure 17- Displaced shape, MK12 RES, 46 mph yielding 


\section{A回田US}

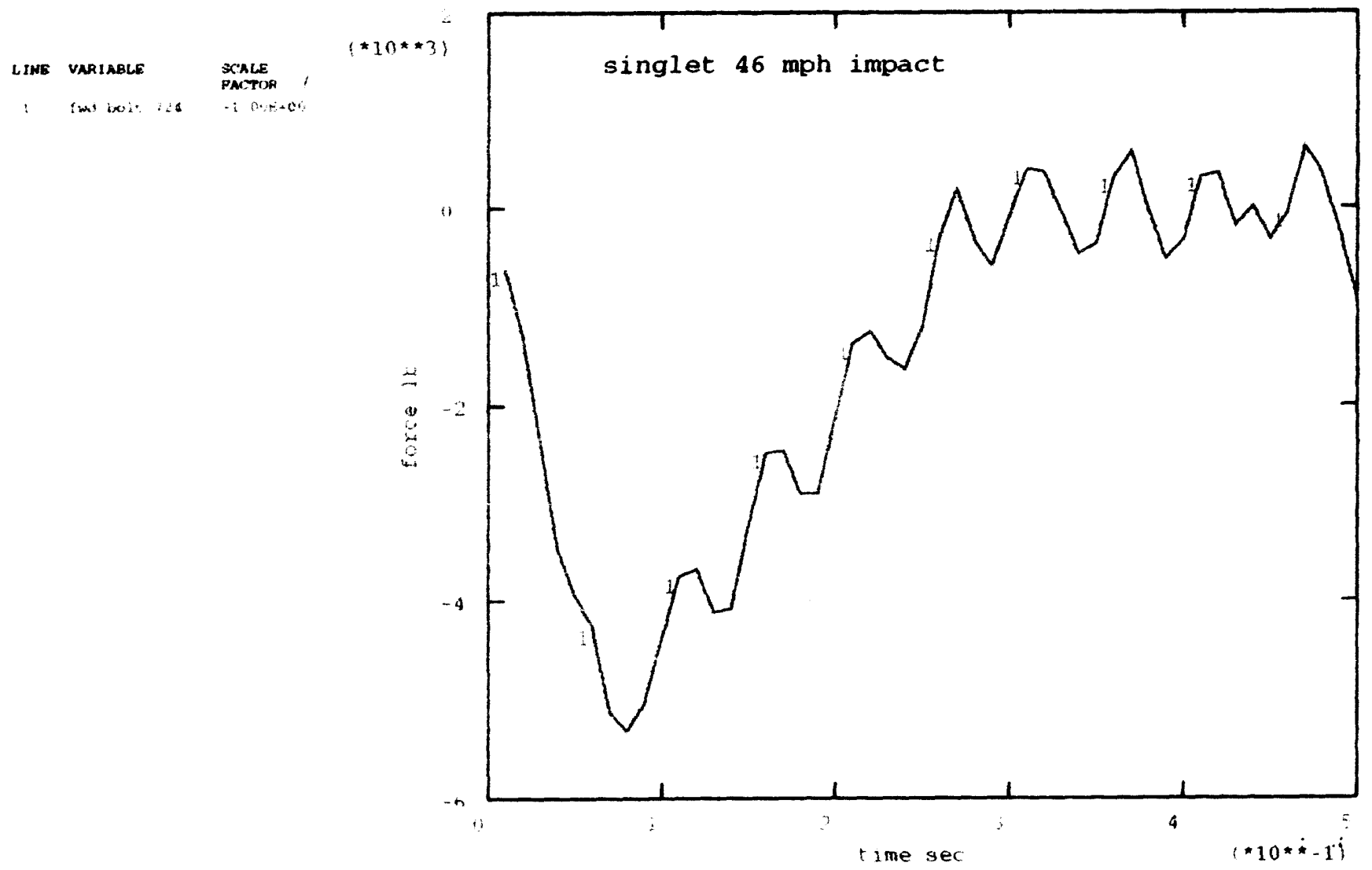

Figure 18- Force in forward clamp pin, MK21 singlet RES, $46 \mathrm{mph}$ unyielding 


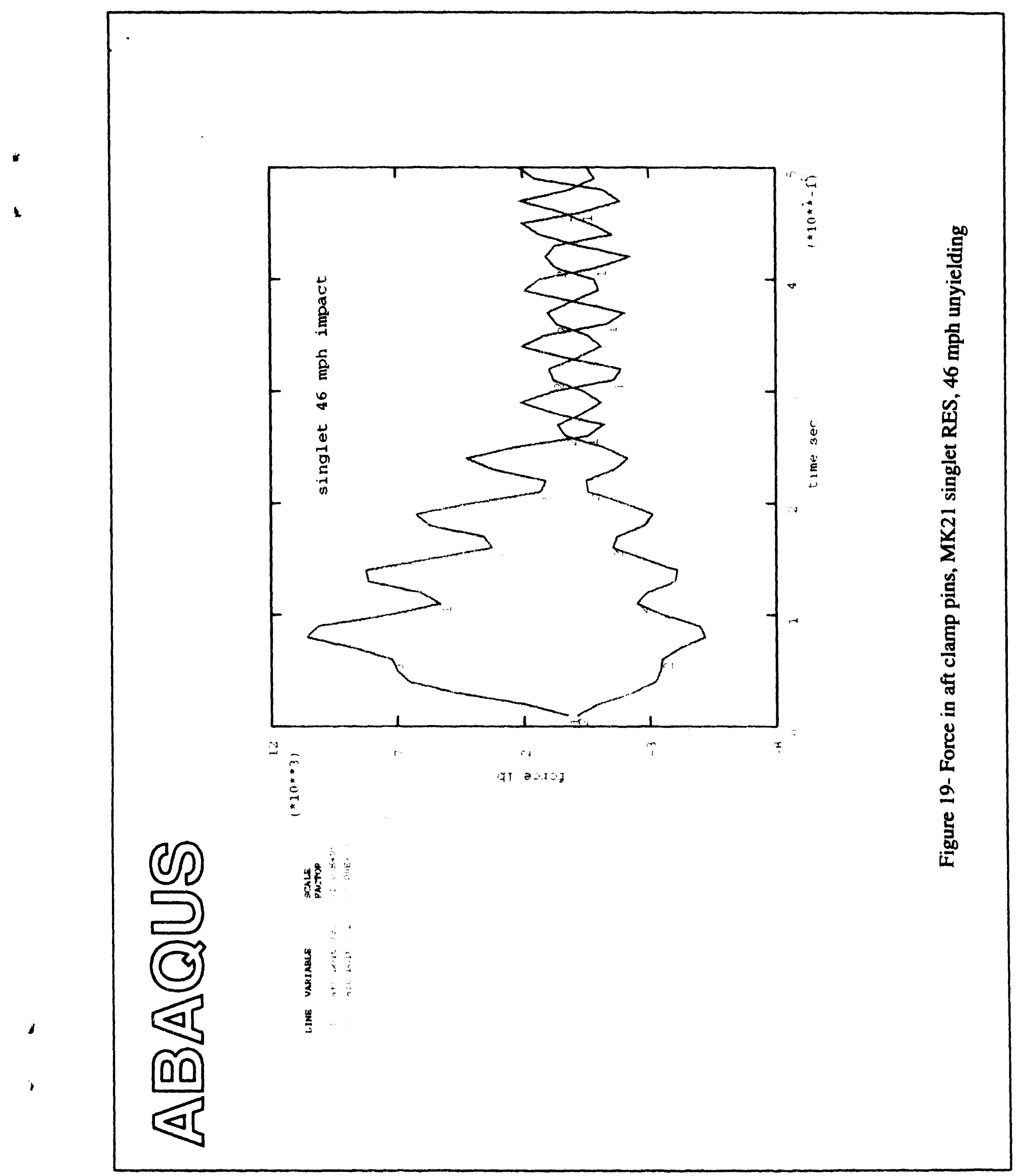




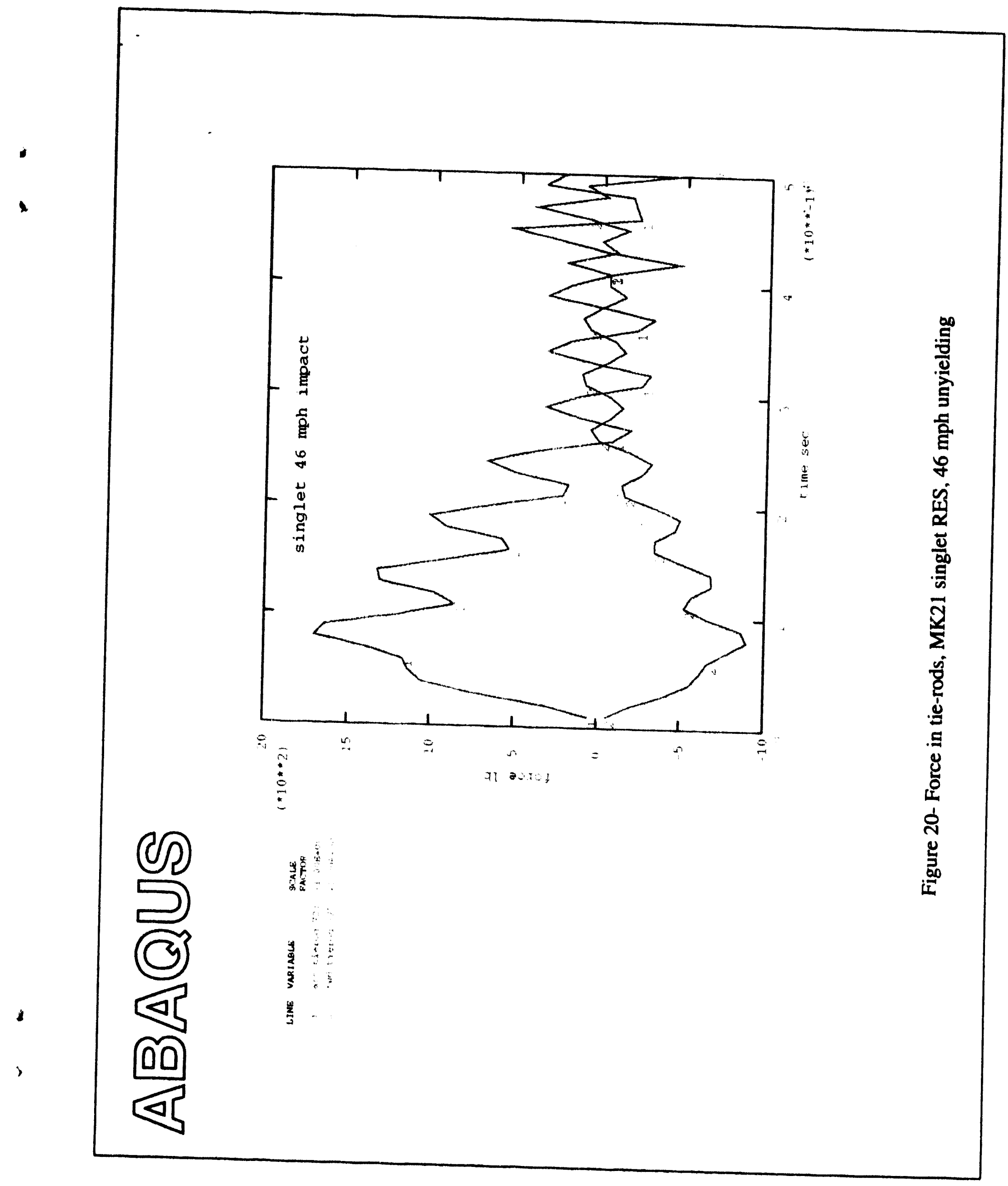




\section{A回@US}

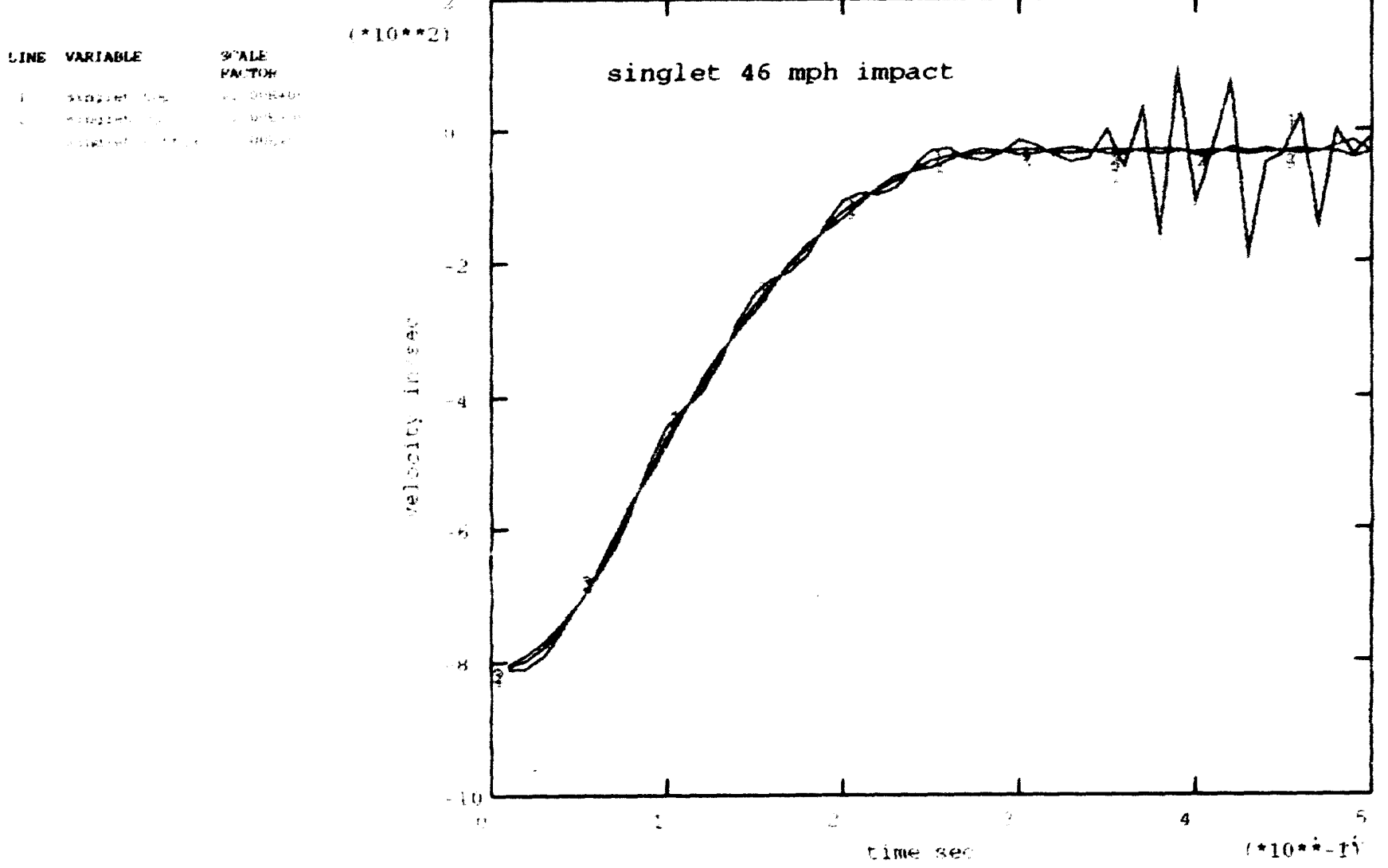

Figure 21- Velocity of MK21 singlet RES, 46 mph unyielding 


\section{ABAQUS}

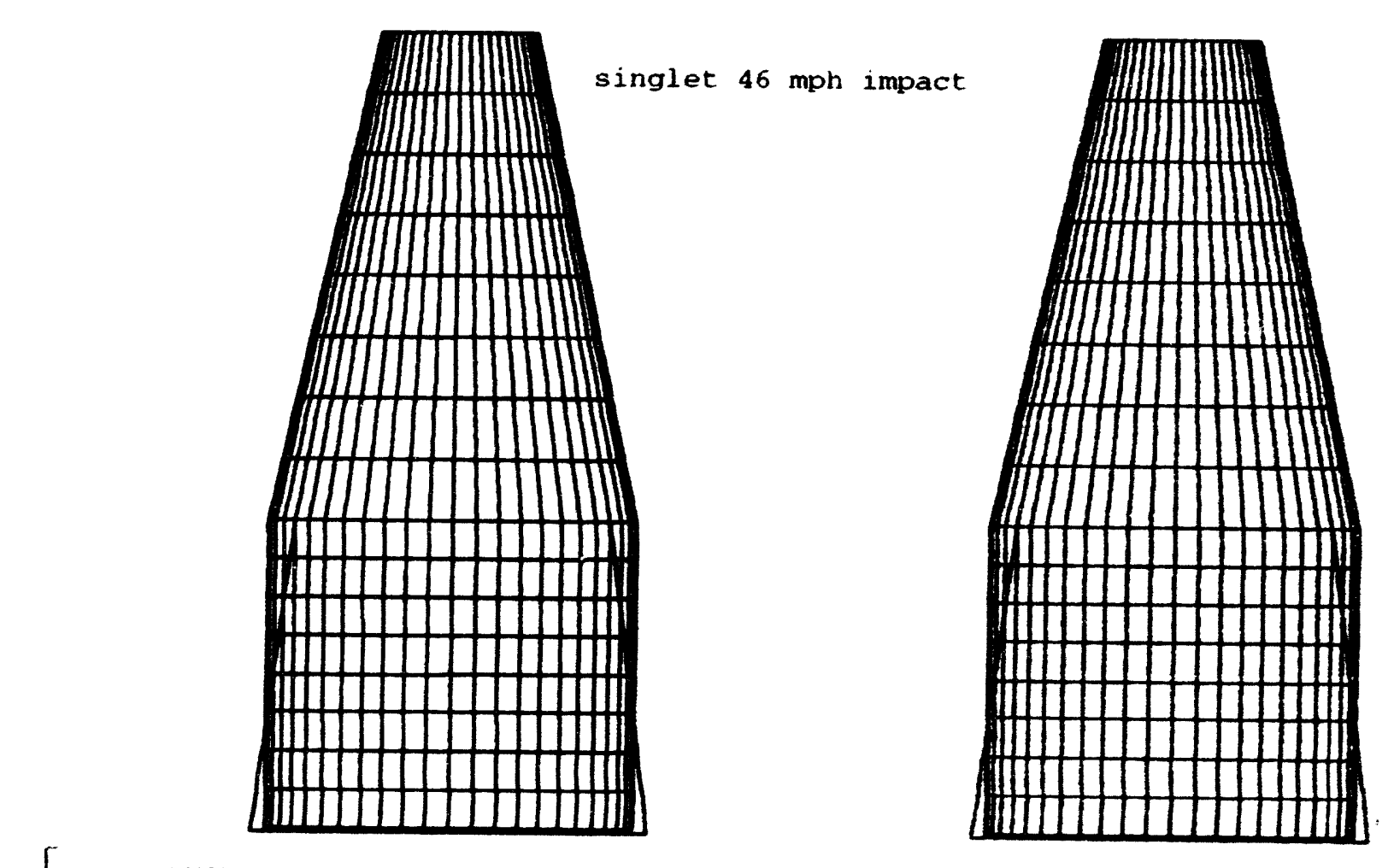

DISPLACEMENT MAKNIFICATION PACTOH $=:$ : OO

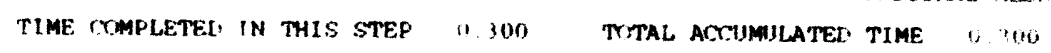

ABANIS VERSION: 5.2-1 DATE: OB-JIN-4S TIME: 09:09:4: STEF 1 INCPEMENT 167760

Figure 22- Displaced shape, MK21 singlet RES, 46 mph unyielding 


\subsection{Appendix A- Lower Support Ring Analysis}

The structural adequacy of the lower support ring is addressed in this section.

The maximum loads seen by the support ring are the loads applied by the four tie-rods. Each tie-rod has a ultimate strennth of $4350 \mathrm{lb}$ (Section 2.2 Load Capabilities). Therefore, the maximum load on the support ring is $4350 \mathrm{lb}$ applied at each of four points.

The ring is attached to the RES at its center of gravity with four each 0.480 in diameter shear pins made from 4130 steel. Each pin has a calculated shear strength of $13,500 \mathrm{lb}$. The shear pins are stucturally adequate.

The lower support ring is 56.00 inch in overall diameter. It has a circular cross section diameter of 2.50 inches and has a wall thickness of 0.188 inches. It is made from 1015-1030 cold drawn steel with an ultimate tensile strength of $60,000 \mathrm{psi}$.

Bending stresses are developed in the ring due to the tie-rod loads which are applied between the radial pin locations. A finite element model of the ring was made of the ring using PATRAN (Reference 2) and ABAQUS (Reference 3). A quarter section was modeled between the attachment pins to the RES. The model consists of 28804 node quadrilateral shell elements. A load of $4350 \mathrm{lb}$ was applied to the mid-point of the quarter section. The predicted Mises stress contours are shown in Figure A1. The maximum stress is less than 30,000 psi. This is much less than the material strength of $60,0000 \mathrm{psi}$.

It is concluded that the ring is structurally adequate. 

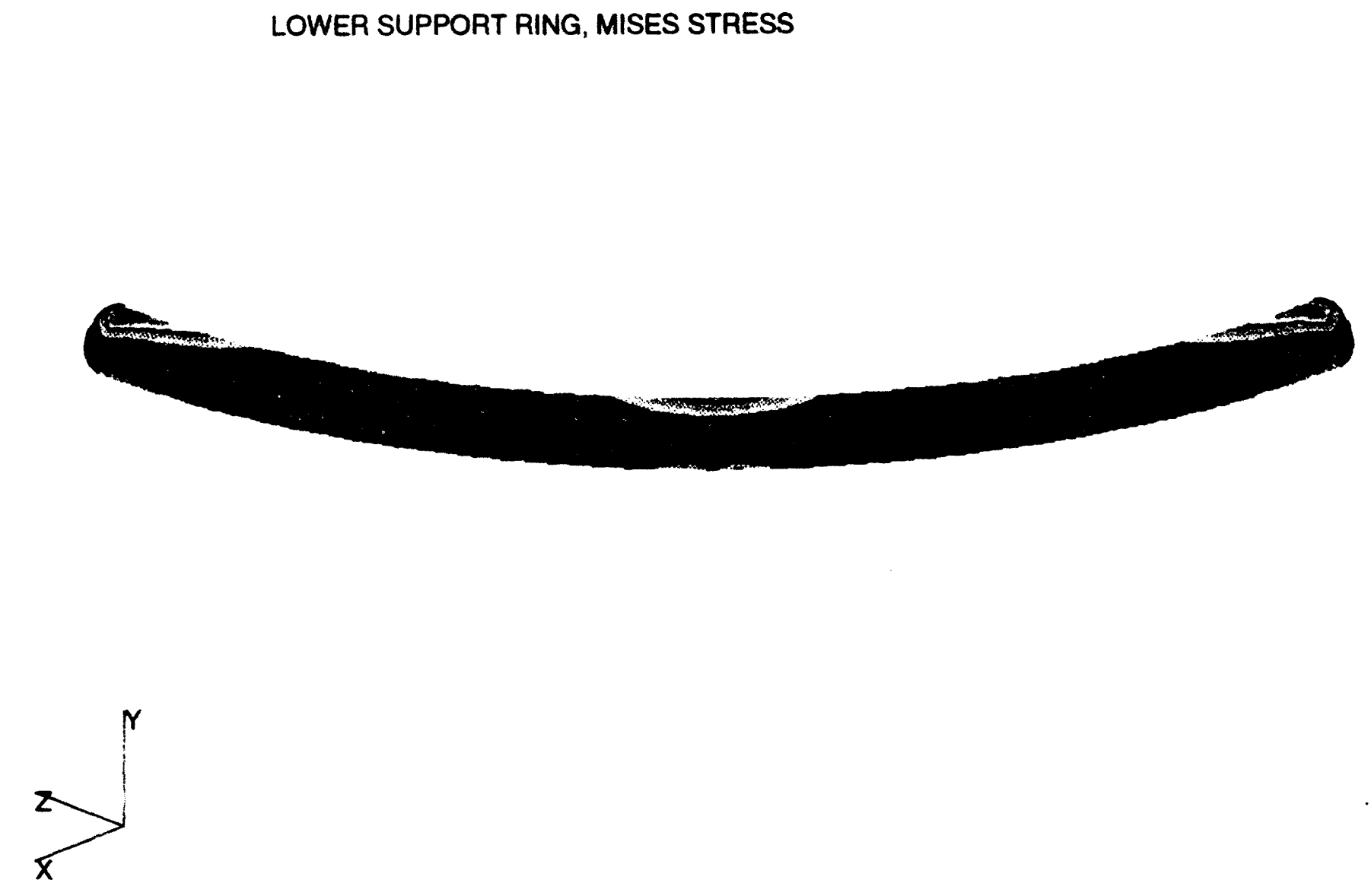

LOWER SUPPORT RING, MISES STRESS

LOWER SUPPORT RING

ABAOUS V5.2-1 19-AUG-93 15:51:02 28802904
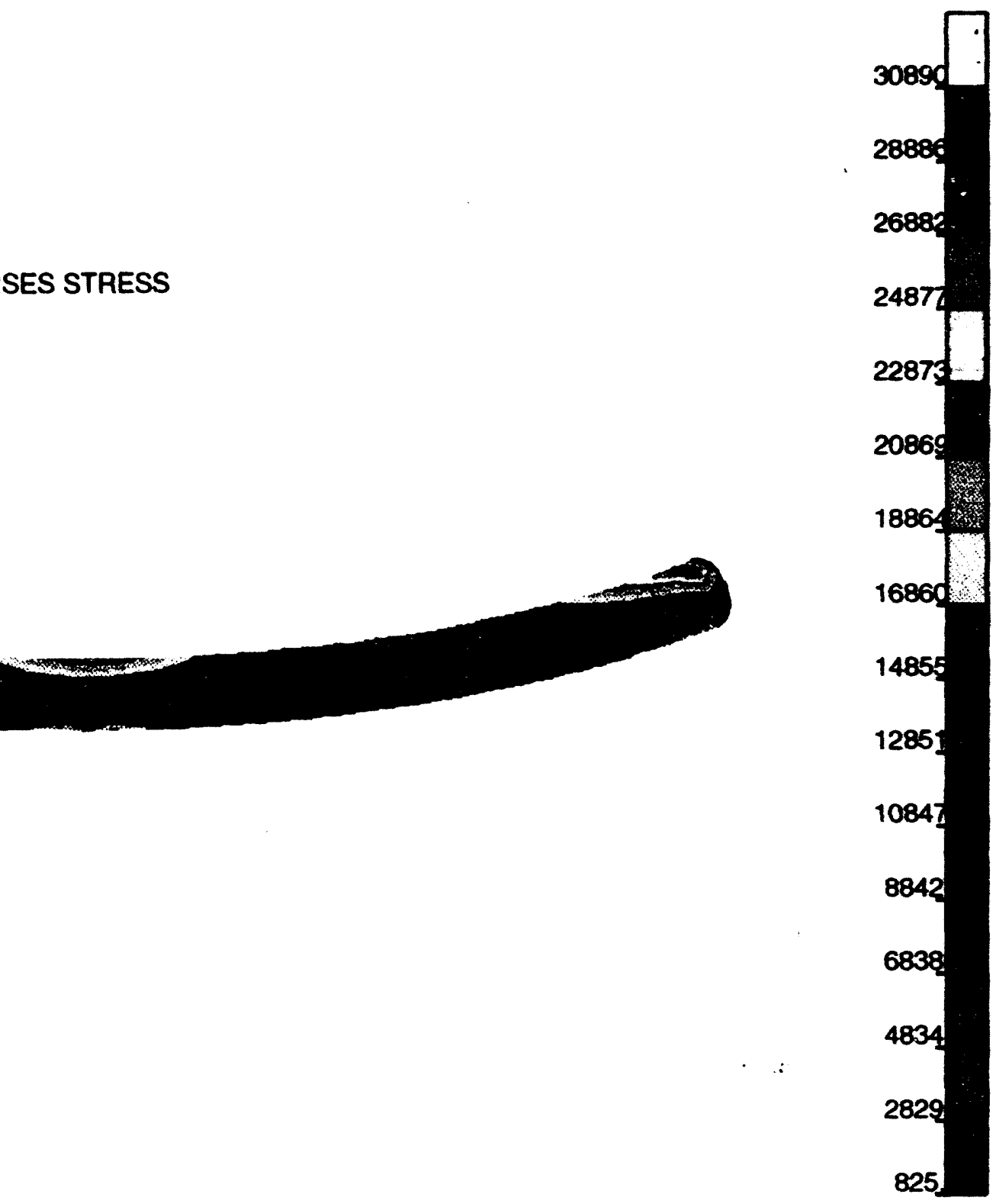

Figure A I- Lower support ring, Mises stress 


\section{Distribution}

LTC Wayne Andrews

HQ DNA/NOSA

6801 Telegraph Road

Alexandria, VA 22310-3398

LCDR Kenneth Stein

HQ DNA/NOSA

6801 Telegraph Road

Alexandria, VA 22310-3398

Gilbert Garcia

OL-NS/ENG

Kirtland AFB, NM 87117

Steve Woodford

RDA

6940 South Kings Highway, Suite 210

Alexandria, VA 22310

Chris Guryan

6940 South Kings Highway, Suite 210

Alexandria, VA 22310

\begin{tabular}{|c|c|c|}
\hline MS0491 & 12333 & P. E. D'Antonio \\
\hline MS0491 & 12333 & C. G. Shirley \\
\hline MS0841 & 1500 & D. J. McCloskey \\
\hline MS0836 & 1501 & $\begin{array}{l}\text { C. W. Peterson } \\
\text { Route to: } 1512,1513,1551,1552\end{array}$ \\
\hline MS0827 & 1502 & $\begin{array}{l}\text { P. J. Hommert } \\
\text { Route to: } 1503,1511,1553,1554\end{array}$ \\
\hline MS0443 & 1561 & H. S. Morgan \\
\hline MS0437 & 1562 & R. K. Thomas \\
\hline MS0437 & 1562 & P. P. Stirbis (10) \\
\hline MS0405 & 6411 & D. D. Carlson \\
\hline MS0899 & 7141 & Technical Library (5) \\
\hline MS0619 & 7151 & Technical Publications \\
\hline MS1119 & $7613-2$ & Document Processing for DOE/OSTI (10) \\
\hline MS9018 & $8523-2$ & Central Technical Files \\
\hline MS9042 & 8741 & G. A. Benedetti \\
\hline MS9043 & 8743 & M. L. Callabresi \\
\hline MS0790 & 9613 & H. J. Abeyta \\
\hline MS0790 & 9613 & B. D. Boughton (10) \\
\hline
\end{tabular}



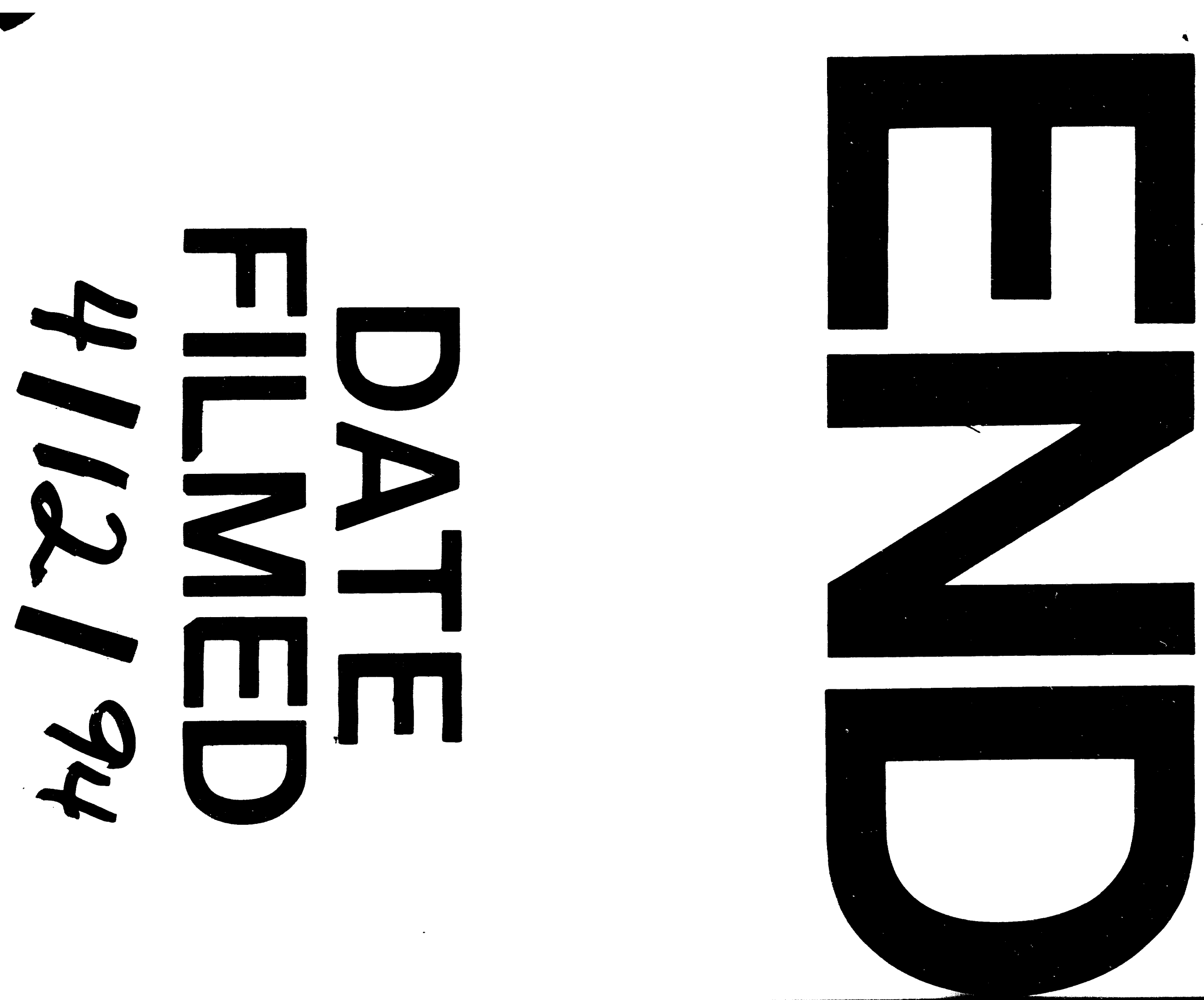
